\title{
Phytoestrogens Modulate Breast Cancer Resistance Protein Expression and Function at the Blood-Cerebrospinal Fluid Barrier
}

\author{
Manjit Kaur, and Raj K. S. Badhan \\ Aston University, Aston Research Centre for Healthy Ageing, School of Life and Health Sciences, Birmingham, UK. \\ Received, January 9, 2015; Revised, April 14, 2015; Accepted, April 30, 2015; Published, May 2, 2015.
}

\begin{abstract}
PURPOSE: Breast cancer resistance protein (BCRP/ABCG2) is a drug efflux transporter expressed at the blood cerebrospinal fluid barrier (BCSFB), and influences distribution of drugs into the central nervous systems (CNS). Current inhibitors have failed clinically due to neurotoxicity. Novel approaches are needed to identify new modulators to enhance CNS delivery. This study examines 18 compounds (mainly phytoestrogens) as modulators of the expression/function of BCRP in an in vitro rat choroid plexus BCSFB model. METHODS: Modulators were initially subject to cytotoxicity (MTT) assessment to determine optimal non-toxic concentrations. Reverse-transcriptase PCR and confocal microscopy were used to identify the presence of BCRP in Z310 cells. Thereafter modulation of the intracellular accumulation of the fluorescent BCRP probe substrate Hoechst 33342 (H33342), changes in protein expression of BCRP (western blotting) and the functional activity of BCRP (membrane insert model) were assessed under modulator exposure. RESULTS: A 24 hour cytotoxicity assay $(0.001 \mu \mathrm{M}-1000 \mu \mathrm{M})$ demonstrated the majority of modulators possessed a cellular viability $\mathrm{IC}_{50}>148 \mu \mathrm{M}$. Intracellular accumulation of $\mathrm{H} 33342$ was significantly increased in the presence of the known BCRP inhibitor Ko143 and, following a 24 hour pre-incubation, all modulators demonstrated statistically significant increases in H33342 accumulation ( $\mathrm{P}<0.001)$, when compared to control and Ko143. After a 24 hour pre-incubation with modulators alone, a 0.16-2.5 -fold change in BCRP expression was observed for test compounds. The functional consequences of this were confirmed in a permeable insert model of the BCSFB which demonstrated that $17-\beta$-estradiol, naringin and silymarin (down-regulators) and baicalin (up-regulator) can modulate BCRP-mediated transport function at the BCSFB. CONCLUSION: We have successfully confirmed the gene and protein expression of BCRP in Z310 cells and demonstrated the potential for phytoestrogen modulators to influence the functionality of BCRP at the BCSFB and thereby potentially allowing manipulation of CNS drug disposition.
\end{abstract}

This article is open to POST-PUBLICATION REVIEW. Registered readers (see "For Readers") may comment by clicking on ABSTRACT on the issue's contents page.

\section{INTRODUCTION}

The blood-brain barrier (BBB) and the bloodcerebrospinal fluid barrier (BCSFB) are the two primary barriers across which endogenous nutrients and hormones and exogenous chemicals must transverse in order to gain access to the central nervous system (CNS). The BBB and BCSFB are often termed the gatekeepers to the CNS and play an obvious role in controlling the neuronal microenvironment. In recent years the importance of the BCSFB as a site for drug metabolism and in governing the composition of cerebrospinal fluid (CSF) has gained more attention due to its significance in normal physiology and disease pathology (1). The BCSFB is formed from the epithelial cells of the choroid plexus (CP) facing the CSF, which are sealed by the tight junctions (2).
The choroid plexuses are located within the brain ventricles: one in each lateral ventricle, the third ventricle and fourth ventricle. The CP epithelium is a dynamic tissue which has a greater perfusion rate compared to the cerebral blood flow and weighing only $2 \mathrm{~g}$ (3-6). It secretes CSF at a rate of $25 \mathrm{~mL} /$ hour in humans (7) which helps to maintain brain extracellular fluid (ECF) and CSF homeostasis $(2,8)$ as well as providing mechanical support to the brain, removal of metabolic products (9) and as a route for the distribution of nutrients, neurotransmitters and hormones across the CNS $(10,11)(12,13)$.

Corresponding Author: Raj K. S. Badhan; Aston University, Aston Research Centre for Healthy Ageing, School of Life and Health Sciences, Birmingham, UK; Email: r.k.s.badhan@aston.ac.uk 
A key component of the protective mechanism of the BCSFB is the expression of a variety of ATP-Binding Cassette (ABC) transporter proteins (14-18), which play a significant role in drug transport across the BCSFB. A key member of the ABC family of transporters is the breast cancer resistance protein (BCRP/ABCP/MXR). BCRP is the second member of the G-subfamily of transporter proteins, and derives it names from the result of its almost simultaneous identification in the drugresistant breast cancer cell line MCF-7/AdrVp (19), human placenta (ABCP) (20) and in a mitoxantrone-resistant cell line (MXR) (21). BCRP mRNA encodes for a 655-amino acid, $72 \mathrm{kDa}$ protein which forms a single nucleotide binding domain (NBD) and six transmembrane domains (TMD), hence is often termed a halftransporter. The endogenous function of BCRP is varied, and can be found expressed in stem cells (22-24), the apical membrane of enterocytes, the liver canaliculi, the proximal tubules of the kidneys, the BBB and BCSFB, the blood-testes barrier and the blood-placental barrier and bloodretinal barriers (25-29). The localisation at key secretory organs results in BCRP imparting a 'protective' pharmacokinetic function for human physiology and limits access of drugs to various tissues.

Much work has focused on the role of BCRP in governing drug penetration across the BBB and rodent knock-out systems have implicated BCRP playing a more complicated role in cooperation with other transporter proteins to limit BBB penetration of drugs, e.g. topotecan (30). Furthermore position-emission tomography studies with tariquidir (31), gefitinib $(32,33)$, sorafenib (34), CEP-32496 (35) have confirmed the importance of BCRP at the BBB. At the BCSFB, only a handful of reports have demonstrated expression in the choroid plexus of mice (36), rats (37) and humans (38). The localisation of BCRP at the CSF side suggests that it would facilitate but not restrict the transport to the $\operatorname{CSF}(37,38)$.

In vitro and in vivo inhibition of BCRP is of great interest for improving the pharmacokinetics of therapeutics. The first series of reported inhibitors included cyclosporine A, pantoprazole and verapamil but demonstrated limited clinical efficacy due to significant toxicity and interactions with CYP3A (39, 40). Second generation inhibitors included topotecan, irinotecan, gefitinib and $\mathrm{SN}-38$ but again demonstrated limited clinical application due to a range of cytotoxicity concerns and high potential for drug-drug interactions $(39,41)$. Third generation inhibitors represent molecules that have been recently developed and include the fungal toxin derived fumitremorgin C (FTC) (42, 43), GF120918, Ko143 (43-45) but again widespread clinical use is limited due to an uncertain safety profile (43). Therefore, there is an urgent need to identify novel inhibitors of BCRP with a tolerable safety profile.

To this end, a novel class of compounds that have gained interest as potential candidates are phytoestogens, of which flavonoids are the most chemical group. Flavonoids are polyphenolic compounds found in fruit, vegetables and many herbal products. In the U.S. the average daily intake of flavonoids has been estimated to be at 1 g (46). In epidemiological and animal studies, flavonoids have been suggested to be possess anti-inflammatory $(47,48)$, anti-oxidative, antithrombogenic $(49,50)$, anti-tumour (51) and anti-viral $(52,53)$ effects.

Numerous studies have demonstrated a direct interaction of flavonoids with BCRP, resulting in the modulation of its activity (Table 1).

Table 1. Various cell lines studied to investigate at the interaction of flavonoids with BCRP.

\begin{tabular}{lll}
\hline Cell line & Flavonoid & Reference \\
\hline MCF-7 & $\begin{array}{l}\text { Apigenin, genistein, naringenin, quercetin, biochanin A, hesperitin, } \\
\text { silymarin and fistein }\end{array}$ & $(54-58)$ \\
NCI-H60 & $\begin{array}{l}\text { Apigenin, naringenin, quercetin, biochanin A, hesperitin, silymarin } \\
\text { and fistein }\end{array}$ & $(56,57)$ \\
BT-474 & Apigenin and genistein & $(54,58)$ \\
T47-D & Apigenin and genistein \\
Caco-2 & $\begin{array}{l}\text { Apigenin, genistein, naringenin, quercetin, biochanin A, hesperitin, } \\
\text { silymarin and fistein }\end{array}$ & $(59-62)$ \\
K562 & Rutin, hespiridin and silymarin & $(55)$ \\
\hline
\end{tabular}


The impact of flavonoids/modulators on CNS drug disposition is highlighted in Figure 1. Under 'normal' physiological conditions BCRP would play a role in the efflux of substrates from the brain endothelial microvascularate back into the systemic circulation and thereby limiting brain ISF exposure. At the BCSFB BCRP would potentially enhance the disposition of drugs into the CSF, with potential CSF-ISF mixing before exiting through CSF drainage routes. This overall balance of drug disposition would therefore favour the CSF. Where flavonoids/modulators are thought to either directly inhibit or down-regulate BCRP protein expression, the effects would be reversed with enhanced $\mathrm{BBB}$ penetration and brain ISF disposition coupled with diminished delivery across the BCSFB and into the CSF (due to the lack of CSF penetration enhancement provided by BCRP under normal conditions). Under circumstances where BCRP is induced, the balance of disposition would favour CSF delivery provided by the enhanced additional transport in the blood-CSF as a result of increased abundance of BCRP at the BCSFB.

In the current study, we identified and investigated the genomic and protein expression of BCRP in immortalised rat choroid plexus cells and the potential for modulation of BCRPmediated transport at the BCSFB using reported phytoestrogenic and non-phytoestrogenic modulators of BCRP expression and function to ascertain whether such modulators can be employed as agents to alter the disposition of transporter substrates at the BCSFB.

\section{MATERIALS AND METHODS}

\footnotetext{
Materials

Dulbecco's modified essential media with glucose (DMEM), fetal bovine serum (FBS), amphotericin $\mathrm{B}$, penicillin/streptomycin and gentamycin were obtained from Biosera (Sussex, UK); Resveratrol and Ko143 from Santa Cruz Biotechnology (Texas, USA); Curcumin from Cayman Chemical (Cambridge, UK); Rat tail I collagen solution from First Link (Birmingham, UK) and all other chemicals were sourced from Sigma (Dorset, UK). GenElute Total RNA extraction kits were purchased from Sigma (Dorset, UK); My Taq ${ }^{\mathrm{TM}}$ one-step RT-PCR kit and Easy Ladder I obtained from Bioline (London, UK). All PCR primers were designed synthesised by IDTDna (Leuven, Belgium); Optiblot SDS-page gel and western blot reagents obtained from Abcam (Cambridge, UK); ABCG2 (M-70), beta-actin (C4), broad
}

range markers, goat anti-rabbit IgG-FITC and protease inhibitor cocktail were obtained from Santa Cruz Biotechnology (Texas, USA). Stock solutions of all test compounds were prepared in dimethylsulfoxide (DMSO) and stored at $-20^{\circ} \mathrm{C}$ until use.

\section{Cell culture}

The rat choroid plexus cell line Z310 was a kind gift from Dr. Wei Zheng (Purdue University, West Lafayette, USA). The cells were maintained in the medium as described by Zheng et al (63) with minor modifications. In brief, cells were grown in DMEM supplemented with $4.5 \mathrm{~g} / \mathrm{L}$ glucose, $10 \%$ FBS, $100 \mathrm{IU} / \mathrm{mL}$ penicillin, 100 $\mu \mathrm{g} / \mathrm{mL}$ streptomycin, $2.5 \mathrm{mg} / \mathrm{mL}$ gentamycin, amphotericin $\mathrm{B}$ and epidermal growth factor (EGF) to a final concentration of $10 \mathrm{ng} / \mathrm{mL}$ in a humidified atmosphere of $5 \% \mathrm{CO}_{2}$ at $37^{\circ} \mathrm{C}$. Cells were used at passages 224-260.

\section{Reverse-transcriptase polymerase chain analysis}

RNA was extracted according to manufacturer's instructions. In brief, cells were seeded at cell density of $5 \times 10^{4}$ per well in a 6 -well plate. Cells were lysed and transferred into a GenElute Total RNA mini prep kit filtration column and centrifuged at $12,000 \mathrm{x} \mathrm{g}$ for 2 minutes. The lysate was transferred into a fresh column and centrifuged. The column was washed twice with wash solution and $50 \mu \mathrm{L}$ of the elution solution was added into the binding column and centrifuged. The concentration of total extracted RNA was quantified by a Nanodrop system (Thermo Scientific, Nanodrop 1000).

RNA amplification was conducted using the My Taq One-Step RT-PCR kit according to the manufactures instructions. The PCR primers used were as follows: TTR (accession number: NM 022712) forward primer 5'ATTAGAGCTTGGTGCATGCCT, reverse primer 5'- GGCCACAACTCACTGGACTT; $\beta$ actin (accession number: NM 031144) forward primer 5'- CCCGCGAGTACAACCTTCTT and reverse primer 5' AACACAGCCTGGATGGCTAC; BCRP (accession number: NM_181381) forward primer 5' - TGTGAGCCCTACAACAACCC, reverse primer 5' - AAAAAGCCTCCACCGTCCTC. The thermal cycle was run as recommend by the manufacturer's kit and the amplified products were separated and visualised using a $1 \%$ agarose gel stained with ethidium bromide. 


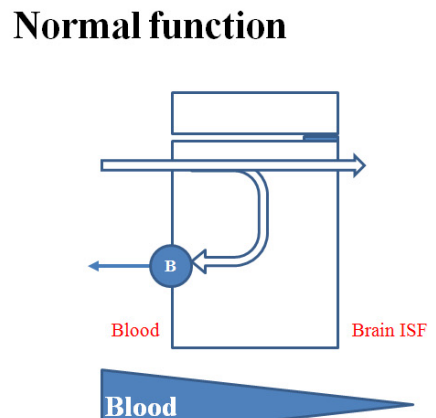

Inhibition/Down-regulation

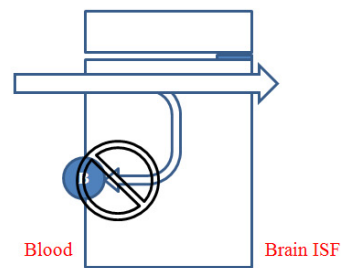

Brain

\section{Up-regulation}

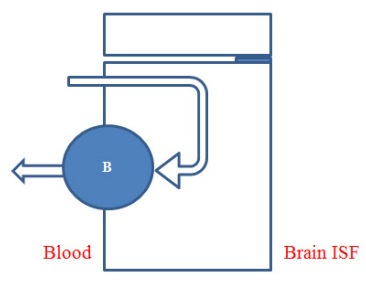

Blood

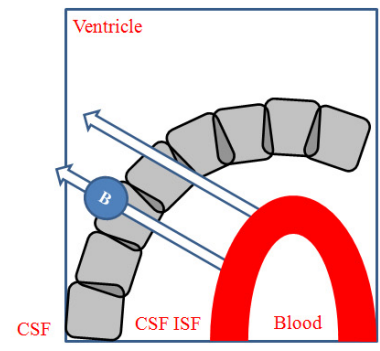

CSF
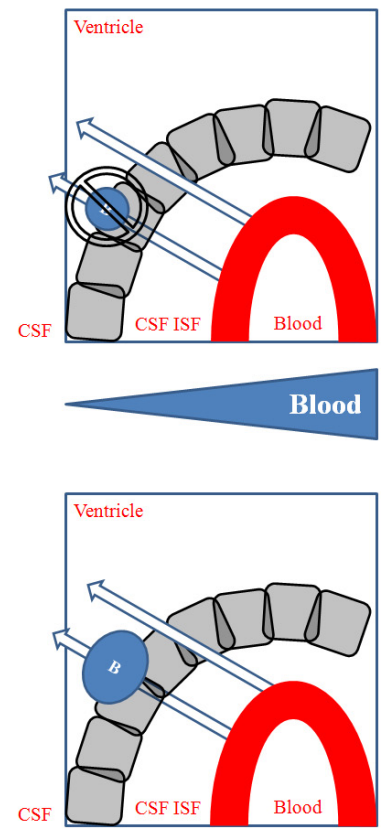

CSF

Figure 1. Balance of drug disposition at the BBB and BCSFB during normal physiological function of BCRP (top), when BCRP is inhibited or down-regulated (middle) and when BCRP is up-regulated (bottom). Arrows indicate the direction of flux; blue triangles indicate the overall balance of disposition; B: BCRP; CSF: cerebrospinal fluid; ISF: interstitial fluid.

\section{Immunofluorescence}

Approximately 15,000 cells were seeded onto glass cover slips for 48 hours and subsequently washed with phosphate buffered saline (PBS) three times and fixed with $4 \%$ paraformaldehyde for 10 minutes at room temperature (RT), washed a further three times with PBS and blocked with 5 $\%$ goat serum in Tris buffer saline tween-20 (TBST) for 30 minutes at RT. The blocking buffer was removed and incubated with primary antibody (ABCG2 M-70) for 2 hours at RT. Cells were washed again with the PBS and incubated with goat anti-rabbit IgG-FITC in the dark for 1.5 hours at RT and mounted with DAPI-containing mounting media.

\section{Confocal Laser Scanning Microscopy}

The cover slips were analysed using an upright confocal microscope (Leica SP5 TCS II MP) and visualised with a 40x oil immersion objective. All images were acquired using an argon laser at 494 $\mathrm{nm}$ to visualise FITC and a helium-neon laser to visualise DAPI at $461 \mathrm{~nm}$.

\section{Modulators}

A total of 18 modulators (Table 2) consisting primarily of flavonoids, were dissolved in DMSO and stored at $-20^{\circ} \mathrm{C}$ until required. 


\begin{tabular}{|c|c|c|}
\hline Modulator Class & Name & Impact on BCRP \\
\hline Diarylheptanoid & Curcumin & $\begin{array}{l}\text { SD Rats (Inhibition) (64); FVB Mice (Inhibition: Increase in } \\
\left.\text { Cmax and } \mathrm{AUC}_{0-8}\right)(65) \text {; Humans (Inhibition: Increase in Cmax and } \\
\left.\mathrm{AUC}_{0-24}\right)(64) ; \mathrm{MCF}-7 \text { (Induction) (66) }\end{array}$ \\
\hline Flavone & Apigenin & $\begin{array}{l}\text { MCF-7 MX100 and NCI-H460 MX20 (Inhibition) and } \\
\text { K562/BCRP (Inhibition) (67) }\end{array}$ \\
\hline Flavone & Baicalin & Caco-2 (Substrate) (68) \\
\hline Flavone & Chrysin & Caco-2 (Inducer-mRNA) (66) \\
\hline Flavone & Flavone & Caco-2 (Inducer-mRNA) (66) \\
\hline Flavone & $\alpha$-napthoflavone & $\begin{array}{l}\text { Aryl-Hydrocarbon Receptor }[\mathrm{AhR}] \text { antagonist (BCRP regulator) } \\
\text { (69) }\end{array}$ \\
\hline Flavone & $\begin{array}{l}6,2,4-\text { Trimethoxy- } \\
\text { flavone (TMF) }\end{array}$ & $\begin{array}{l}\text { Aryl-Hydrocarbon Receptor }[\mathrm{AhR}] \text { antagonist (BCRP regulator) } \\
\text { (70) }\end{array}$ \\
\hline Flavonol & Fisetin & MCF-7 MX100 and NCI-H460 MX20 (67) \\
\hline Flavonol & Quercetin & $\begin{array}{l}\text { Caco-2 (Inducer-mRNA) (66); HEK293/BCRP (71); } \\
\text { MCF7/MX, K562/BCRP (Inhibition) (72) }\end{array}$ \\
\hline Flavonol & Reservatrol & $\begin{array}{l}\text { Aryl-Hydrocarbon Receptor [AhR] antagonist (BCRP regulator) } \\
\text { (73); } \\
\text { Caco-2 and MCF-7 (Inducer-Protein) (66). }\end{array}$ \\
\hline Flavonol glycoside & Rutin & Membrane vesicles (Inhibition) (74) \\
\hline Flavonolignan & Silymarin & $\begin{array}{l}\text { MCF-7 MX100 and NCI-H460 MX20 (Inhibition) } \\
\text { (67); } \\
\text { Caco-2 (Inducer-Protein) (66) }\end{array}$ \\
\hline Flavanone & Hesperidin & Unknown \\
\hline Flavanone & Hesperetin & MCF-7 MX100 and NCI-H460 MX20 (Inhibition) (67) \\
\hline $\begin{array}{l}\text { Flavanone } \\
\text { glycoside }\end{array}$ & Naringin & MCF-7 MX100 and NCI-H460 MX20 (Inhibition) (67) \\
\hline $\begin{array}{l}\text { O-methylated } \\
\text { isoflavone }\end{array}$ & Biochanin A & MCF-7/MX100 (Inhibition) $(67,75)$ \\
\hline $\begin{array}{l}\text { Polycyclic aromatic } \\
\text { hydrocarbon }\end{array}$ & Benzo(a)pyrine (BAP) & $\begin{array}{l}\text { Aryl-Hydrocarbon Receptor [AhR] agonist (BCRP regulator) } \\
\text { leading to BCRP modualtion }(76)\end{array}$ \\
\hline Oesteogens & $17-\beta$-Estradiol & $\begin{array}{l}\text { Estrogen receptor agonist (BCRP regulator) and } \\
\text { SD Rats (Inhibition) leading to pronounced BCRP downregulation } \\
\text { (77) }\end{array}$ \\
\hline
\end{tabular}

\section{Cytotoxicity assay}

$5 \times 10^{4}$ cells per well were seeded into the 96-well plate and allowed to attach for 24 hours. The media was subsequently removed and cells washed with PBS, followed by the addition of 200 $\mu \mathrm{L}$ of growth media containing modulators per well across a seven-fold log concentration range (0.001-1000 $\mu \mathrm{M})$ and incubated for 24 hours at $37^{\circ} \mathrm{C}$ in a $5 \% \mathrm{CO}_{2}$ air humidified environment. Thereafter $20 \quad \mu \mathrm{L}$ of $5 \quad \mathrm{mg} / \mathrm{mL} \quad 3-(4,5-$ dimethylthiazol-2-yl)-2,5-diphenyltetrazolium bromide (MTT) dissolved in PBS was added to each well and incubated at $37^{\circ} \mathrm{C}, 5 \% \mathrm{CO}_{2}$ in an air humidified environment for 4 hours. After incubation the medium was removed and $100 \mu \mathrm{L}$ of DMSO was added. Plates were left in dark for 5-15 minutes and the UV-absorbance of the formazan product was determined at $595 \mathrm{~nm}$. Each concentration was assayed in eight wells and run in three independent experiments and results 
expressed as percentage cytotoxicity relative to a non-modulator control (exposed to $0.5 \%$ DMSO only).

\section{Hoechst 33342 intracellular accumulation assay}

To assess the impact of modulators on the intracellular accumulation of a BCRP substrate, a fluorescent BCRP substrate, Hoechst 33342 (H33342), was utilised in a 96-well plate format accumulation assay. $2 \times 10^{4}$ cells were seeded into each well of 96-well plate and allowed to attach for 48 hours. The media was removed and cells were washed twice with $100 \mu \mathrm{L}$ warm Hanks balances salt solution (HBSS) and pre-incubated with an optimal concentration of modulator (as determined from the MTT assay) for 24 hours in cell culture media with a no-modulator control (0.5\% DMSO). After 24 hours the cells were washed with ice cold HBSS and incubated with $25 \mu \mathrm{M} \mathrm{H} 33342$ alone, for one hour in HBSS supplemented with $10 \mathrm{mM}$ HEPES. For comparison to the known specific BCRP inhibitor Ko143, cells were pre-incubated for only 1 hour before incubating with $\mathrm{H} 33342$.

At the end of the incubation period, media was removed and cells were washed with ice cold HBSS and $100 \mu \mathrm{L}$ of the lysis buffer $(50 \mathrm{mM}$ Hepes, $200 \mathrm{mM} \mathrm{NaCl}$, 5\% glycerol and $0.5 \%$ triton-X) was added into each well and the plates shaken on an orbital plate shaker (500 rpm for 2 minutes) before being incubated in the dark for 30 minutes. The wells were read on fluorescent plate reader SpectraMax MX5 reader (Molecular Devices LLC, Sunnyvale, CA) with an excitation wavelength of $355 \mathrm{~nm}$ and emission of $460 \mathrm{~nm}$. Each modulator was assayed in eight wells and run in three independent experiments.

The impact of modulator fluorescence interfering and overlapping with the fluorescence of $\mathrm{H} 33342$ was assessed in a cell-free system using identical modulator and $\mathrm{H} 33342$ concentrations used in the intracellular accumulation assay on a 96 -well plate. $100 \mu \mathrm{L}$ of each modulator and $\mathrm{H} 33342$ were added to wells (quadruplicate) of a 96-well plate and fluorescence measured with an excitation wavelength of $355 \mathrm{~nm}$ and emission of $460 \mathrm{~nm}$.

\section{Modulation of BCRP protein expression}

To assess the impact of modulator exposure on BCRP protein expression, cells were grown in a $25 \mathrm{~cm}^{2}$ flasks for 2-3 days or until confluent and treated with $25 \mu \mathrm{M}$ of modulator (unless otherwise stated) for 24 hours. Cells were washed with warm PBS and whole cell lysate were obtained by trypsinised with $0.5 \%$ trypsin-EDTA. The cell suspension was centrifuged at $1500 \mathrm{rpm}$ for 10 minutes and supernatant was discarded. Freshly prepared ice cold RIPA buffer (1xTBS, $1 \%$ Nonidet P- $40,0.5 \%$ sodium deoxycholate, $0.1 \%$ SDS, $0.004 \%$ sodium azide, $0.01 \%$ PMSF solution, sodium orthovanadate and protease inhibitor cocktail) was added. The lysate was homogenized by ultra-sonication on ice. Cell debris was removed by centrifugation for 30 minutes at $16,000 \times \mathrm{g}$ and $4^{\circ} \mathrm{C}$.

The supernatant was collected and protein content was determined by a bicinchoninic acid assay (BCA). Approximately, $75 \mu \mathrm{g}$ of protein was loaded into each well and transferred onto a PVDF membrane. The membrane was incubated overnight at $4{ }^{\circ} \mathrm{C}$ with a $1: 500$ dilution of BCRP primary antibody (ABCG2-M70). The blot was then incubated with a 1:7500 dilution of a HRPconjugated secondary antibody (goat anti-rabbit IgG conjugated with horseradish peroxidase) on a shaker for 2 hours at RT. For detection of the loading control ( $\beta$-actin) a 1:5000 dilution of a HRP-conjugated beta-actin antibody (C4) was used. Bands were visualised by a laboratory made enhanced chemiluminescence (ECL) solution (90 $\mathrm{mM} p$-coumaric acid, $250 \mathrm{mM}$ luminol, $1 \mathrm{M}$ tris and $30 \% \quad \mathrm{H}_{2} \mathrm{O}_{2}$ ) before development.

\section{In vitro BCSFB model: modulation of BCRP transport function}

Directional transport experiments were conducted in Z310 cells to evaluate the functional activity of BCRP in Z310 cells and to assess the impact of pre-incubation of cells with BCRP modulators on the apical-to-basolaterial (CSF-to-blood) transport of the BCRP substrate sulfasalazine. The porous polyester membrane attached to the inner chamber of a $1.12 \mathrm{~cm}^{2}$ permeable insert $\left(\right.$ ThinCert ${ }^{\circledR}$ ) was pre-coated with $0.01 \%$ collagen for 3-4 hours. The inserts were washed twice with PBS and 1 $\mathrm{mL}$ of cell suspension containing $2.0 \times 10^{5}$ cells in cell culture media supplemented $1 \mu \mathrm{M}$ dexamethasone (78) was added to the insert chamber and $1.5 \mathrm{~mL}$ of cell culture media added to the outer well. The cell monolayer was formed 4-6 days post-seeding and was confirmed by the formation of apical 'CSF' for 24 hours, TEER value of $60 \pm 5 \Omega \cdot \mathrm{cm}^{2}(63,78-83)$ and $<1 \%$ lucifer yellow permeation.

Transendothelial electrical resistance was measured using chop-stick electrodes and corrected for background resistance (collagencoated inserts without cells) and by the surface area of the insert $\left(1.12 \mathrm{~cm}^{2}\right)$. Lucifer yellow (LY) 
permeability assays were conducted using 100 $\mu \mathrm{M}$ of LY (prepared in HBSS) added apically and incubated for 60 minutes at $37^{\circ} \mathrm{C}$ before $100 \mu \mathrm{L}$ samples were removed from the basolateral well. The permeation of LY was assessed using a fluorescent plate reader (SpectraMax MX5 reader: Molecular Devices LLC, Sunnyvale, CA), with an excitation wavelength of $485 \mathrm{~nm}$ and emission of $530 \mathrm{~nm}$.

For transport studies the media was replaced with fresh maintenance media supplemented with $25 \mu \mathrm{M}$ of the modulator and incubated for 24 hours. Thereafter inserts were washed with warm serum free maintenance media (SFM) and incubated with SFM for 30 minutes to equilibrate. Following this equilibration period, $1 \mathrm{~mL}$ fresh SFM was spiked with $10 \mu \mathrm{M}$ sulfasalazine for all wells (with no modulators) and for control wells, $1 \mu \mathrm{M}$ Ko143, added to the insert well and $1.5 \mathrm{~mL}$ of warm SFM added to the outer well. Samples were taken from the outer well at $0,30,60,90$, $120,150,180$ and 210 minutes, replaced with fresh warn SFM and sulfaslazine concentrations analysed by HPLC analysis and corrected for volume replacement.

The apical-to-basolateral apparent permeability coefficient was calculated according to equation 1 :

$\mathrm{P}_{\mathrm{app}, \mathrm{AB}}=\frac{\mathrm{dQ}}{\mathrm{dt}} \times \frac{1}{\mathrm{AC}_{0}}$

where $\mathrm{P}_{\mathrm{app}, \mathrm{AB}}(\mathrm{cm} / \mathrm{s})$ is the apparent permeability coefficient, dQ/dt the amount of drug permeated per unit of time and is calculated from the regression line of time points of sampling, A $\left(\mathrm{cm}^{2}\right)$ is the insert surface area $\left(1.12 \mathrm{~cm}^{2}\right)$ available for permeation and $\mathrm{C}_{0}$ the initial drug concentration in the donor compartment.

\section{High-performance liquid chromatography analysis \\ The isocratic HPLC method utilised within this study was derived from the studies of Elmasry et al., (2011). The HPLC analyses (Shimadzu, LC- 2010A HT) of the samples were performed on a reversed-phase C18 column (Phenomenex Luna $5-\mu \mathrm{m})$ with a mobile phase consisting of 70:29:1 methanol:millQ water:acetic acid, with a flow rate of $1 \mathrm{~mL} / \mathrm{min}$ and a retention time of 7 minutes. In our studies a linear correlation was reported up to}

$50 \mu \mathrm{M}\left(\mathrm{r}^{2}=0.998\right)$ for sulfasalazine prepared in HBSS transport buffer and detected at $365 \mathrm{~nm}$. The lowest limits of quantification were 0.025 $\mu \mathrm{M}$.

\section{STATISTICAL ANALYSIS}

Unless otherwise stated, three independent experiments were carried out for each test compound. Statistical significance was evaluated by one-way ANOVA or paired two-tail Students t-test using GraphPad Prism version 5.00 for Windows (GraphPad Software, La Jolla California USA, www.graphpad.com). Calculations of $\mathrm{IC}_{50}$ were determined using a four-parameter logistic sigmoidal fitting function within GraphPad Prism. Unless otherwise states, data is reported as mean \pm standard deviation (SD). A significance level (P-value) of $<0.05$ was considered as statistically significant.

\section{RESULTS}

\section{Expression and localisation of BCRP in Z310 cells}

The immortalised rat choroid plexus Z310 cell line has previously been used as an in vitro tool to study drug transport at $\operatorname{BCFSB}(37,82)$. To date, only one study has confirmed the presence of BCRP in Z310 cells (37) and based upon this observation, we investigated the presence of BCRP in Z310 cells. Reverse-transcriptase PCR confirmed the presence of BCRP in Z310 cells with an expected product size of 146 base pairs alongside the presence of key choroid plexus phenotypic markers transthyretin (TTR) and $\beta$ actin (BA) loading control (Figure 2A). Furthermore, Z310 were successful shown to be localised in Z310 cells when grown on cover slips and subjected to immunofluorescence staining (Figure 2B).

\section{Cytotoxicity studies}

A 24 hour MTT assay across a seven-fold log concentration range $(0.001 \mu \mathrm{M}-1000 \mu \mathrm{M})$ showed no significant cytotoxicity for the majority of the modulators studied up to $100 \mu \mathrm{M}$, with the lowest cellular viability $\mathrm{IC}_{50}$ attributed to $\alpha$ napthoflavone $\left(\mathrm{IC}_{50}=1.4 \mu \mathrm{M}\right)$ with all remaining modulators demonstrated an $\mathrm{IC}_{50}$ in excess of 148 $\mu \mathrm{M}$ (Figure 3). 
(A)

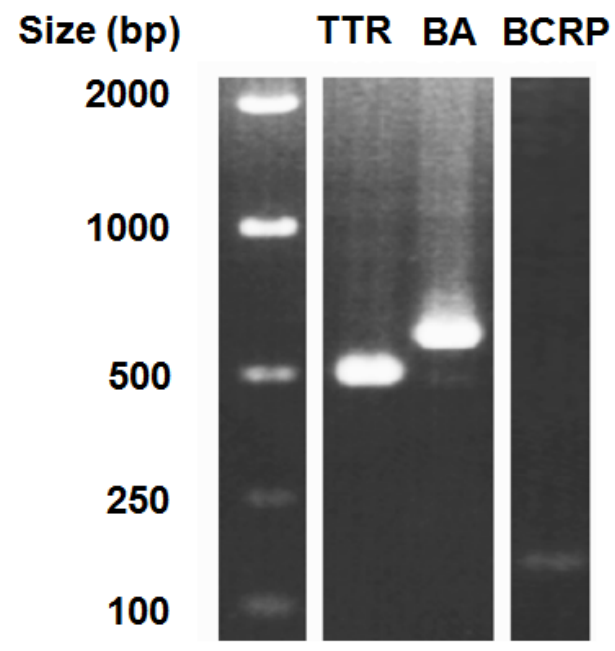

(B)

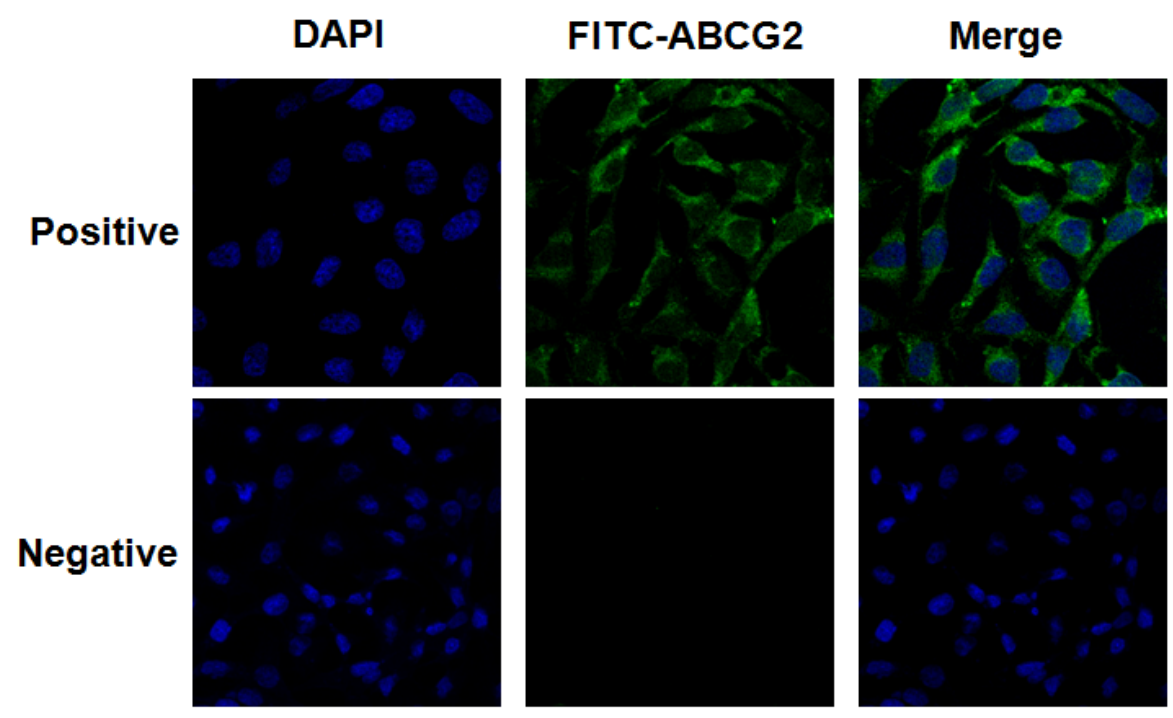

Figure 2. (A) Amplicon products for TTR, loading control (BA) and BCRP; (B) Localisation of BCRP in Z310 cells. Cells were grown on the coverslips for 2-3 days. Z310 cells were fixed with 4\% paraformaldehyde and stained for BCRP using the ABCG2-M70 primary antibody and goat anti-rabbit IgG-FITC secondary antibody (Green). Cell nuclei were visualized using DAPI (Blue). Negative excludes ABCG2-M70 primary antibody but includes FITC secondary, whereas positive includes primary and secondary antibody incubation for BCRP detection.

\section{Hoechst 33342 intracellular accumulation assay}

The functional activity of BCRP was evaluated by measuring the accumulation of H33342, a fluorescent BCRP substrate, following incubation of $\mathrm{H} 33342$ in the presence of modulators and Ko143. Exposure of cells to the BCRP specific inhibitor Ko143, resulted in a significant increase $(\mathrm{P}<0.001)$ in intracellular H33342 accumulation when compared to control (no inhibitor) and with all modulators demonstrating a highly significant increase $(\mathrm{P}<0.0001)$ in $\mathrm{H} 33342$ accumulation compared to control (Figure 4). All modulators demonstrated background-equivalent fluorescence emission with no overlapping fluorescence with H33342 except for baicalin, fisetin and $\alpha$ napthoflavone. Furthermore biochanin-a, chrysin, quercetin, rutin and silymarin demonstrated significantly higher intracellular H33342 accumulation when compared to Ko143 (Figure $4)$.

For the non-phytoestrogenic compounds (BAP, curcumin and $17-\beta$-estradiol), significantly higher RFUs compared to Ko143 were observed for $17-\beta$-estradiol only $(\mathrm{P}<0.001)$, whilst $\mathrm{BAP}$ and curcumin demonstrated significantly higher RFU compared to control only $(\mathrm{P}<0.0001)$. 

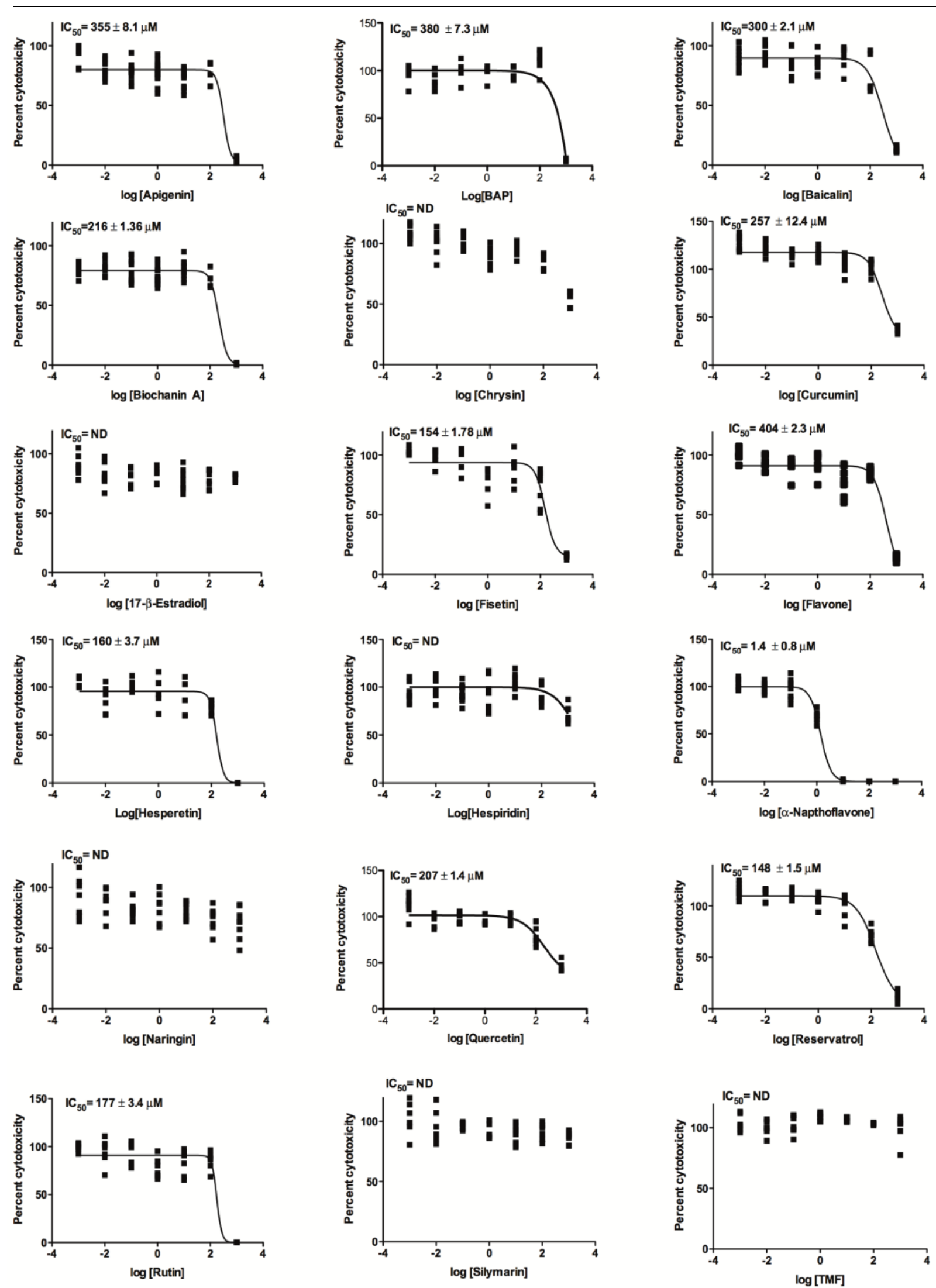

Figure 3. Cytotoxicity of modulators of BCRP on the Z310 cells line. Z310 cells were grown on a 96-well plate for 48 hours and exposed to modulators over a concentration range of 0.001-1000 $\mu \mathrm{M}$ for 24 hours. Data for each modulator is reported as scatter points with up to 8 replications per compound in three independent experiments. ND: not determined. 


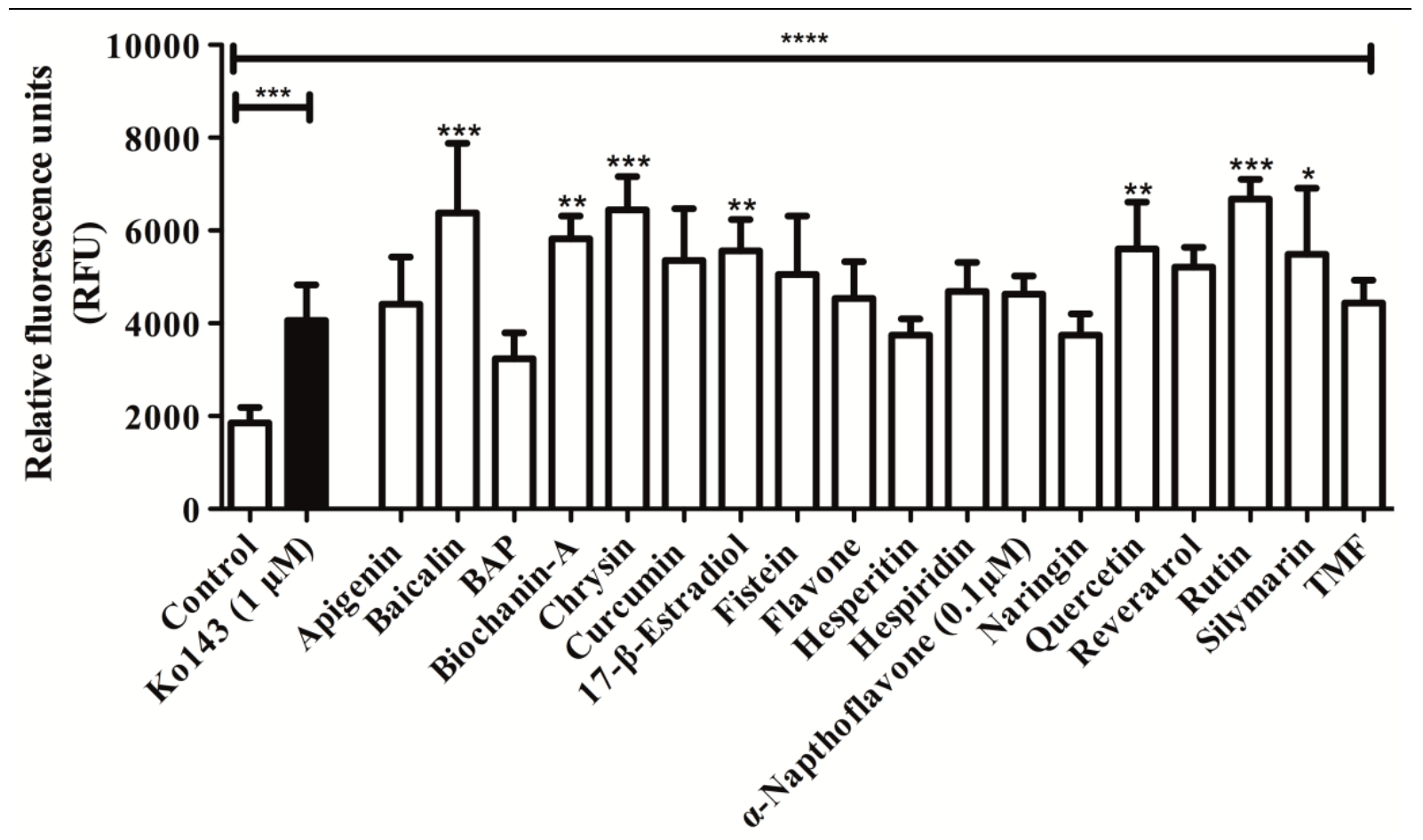

Figure 4. H33342 accumulation assay for BCRP function in Z310 cells. Cells were grown in a 96 well plate for 48 hours and washed with warm HBSS supplemented and incubated for 24 hours with media containing, unless otherwise stated, $25 \mu \mathrm{M}$ of test compound. Subsequently cells were incubated with media containg H33342 for 1 hours and lysed. . Data is represented as mean \pm SD of three independent experiments with $n=6-8$ wells for each modulator in each experiment. Significant differences between Ko143 and modulators are indicated above the appropriate error bars. * $\mathrm{P}$ $\leq 0.05, * * \mathrm{P} \leq 0.01, * * * \mathrm{P} \leq 0.001$ and $* * * * \mathrm{P} \leq 0.0001$.

\section{Modulation of BCRP protein expression}

To investigate the effect of different modulators on BCRP protein expression, Z310 cells were incubated with modulators for 24 hours and western blotting employed to assess any change in BCRP protein expression. BCRP was successfully demonstrated to be expressed in Z310 cells with an expected size of $72 \mathrm{kDa}$ (Figure 5A). A significant increase in BCRP protein was observed for flavone $(2.65 \pm 0.12$ fold $)$, baicalin (2.42 \pm 0.19 fold $)$, hesperidin $(2.43 \pm 0.09$ fold $)$ and BAP (1.61 \pm 0.17 fold) (Figure 5). Furthermore, a significant down-regulation in BCRP was observed for naringin $(0.16 \pm 0.07$ fold) and silymarin ( $0.22 \pm 0.09$ fold), quercetin $(0.29 \pm 0.08$ fold $)$ and $17-\beta$ estradiol $(0.49 \pm 0.11$ fold) (Figure 5A).

\section{In vitro BCSFB model: modulation of BCRP transport function}

In the presence of $1 \mu \mathrm{M}$ of the BCRP specific inhibitor Ko143, a significant increase in the apical-to-basolateral transport of sulfasalazine was observed across all time points $(\mathrm{P}<0.05)$ (Figure 6a). Similarly modulators resulting in down-regulation of BCRP in western blots analysis (section 3.5), namely 17- $\beta$-estradiol (Figure 6c), naringin (Figure 6e) and silymarin (Figure 6f) also demonstrated a significant $(\mathrm{P} \leq$ 0.05 ) increase in sulfasalazine apical-tobasolateral transport at the end of the study period. Baicalin (Figure $6 \mathrm{~b}$ ) and flavone (Figure 6d) demonstrated an up-regulation of BCRP protein expression (Figure 5) but only baicalin demonstrated a significant decrease $(\mathrm{P} \leq 0.05)$ in the apical-to-basolateral transport of sulfasalazine at earlier time points (60 minutes to 150 minutes) when compared to control.

The apparent permeability $\left(\mathrm{P}_{\mathrm{app}, \mathrm{AB}}\right)$ of sulfasalazine was found to be $1.32 \times 10^{-6} \pm 0.12$ $\times 10^{-6} \mathrm{~cm} / \mathrm{s}$, and this was significantly increased to $2.11 \times 10^{-6} \pm 0.09 \times 10^{-6} \mathrm{~cm} / \mathrm{s}$ when exposed to the specific BCRP inhibitor Ko143 (Table 3), demonstrating the functional activity of BCRP in Z310 cells. Furthermore, naringin, silymarin and $17-\beta$-Estradiol also resulted in significant increases in sulfasalazine apical-to-basolateral permeability; $3.83 \times 10^{-6} \pm 0.34 \times 10^{-6} \mathrm{~cm} / \mathrm{s}$, $3.33 \times 10^{-6} \pm 0.61 \times 10^{-6} \mathrm{~cm} / \mathrm{s}$ and $2.01 \times 10^{-6} \pm 0.23$ $\mathrm{x} 10^{-6} \mathrm{~cm} / \mathrm{s}$ respectively (Table 3 ). 
(A)

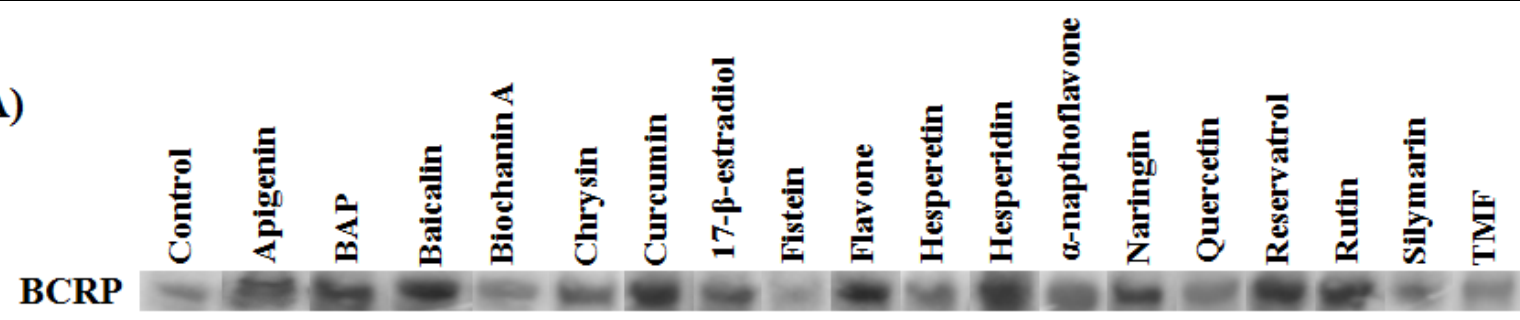

$\beta$-actin

(B)

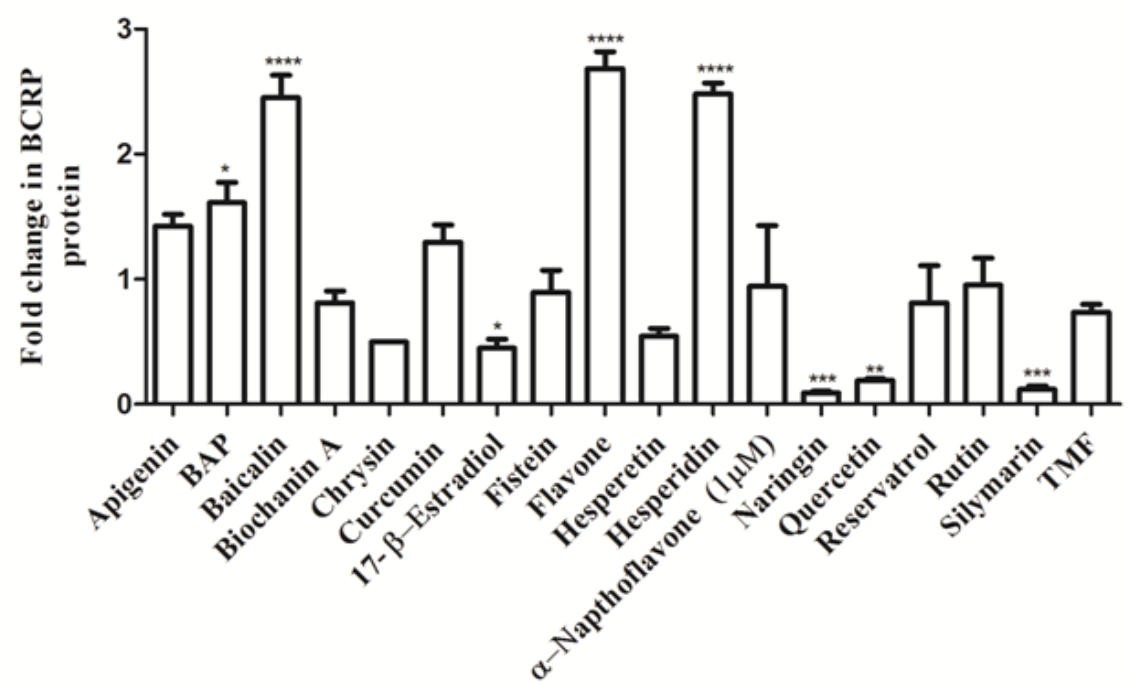

Figure 5. (A) Western blot results of modulator incubation with Z310 cells. Modulators were prepared in media to a final concentration of $25 \mu \mathrm{M}(0.1 \mu \mathrm{M}$ for $\alpha$-napthoflavone) and incubated with cells for 24 hours followed by extraction of whole cell lysate and separation of protein on an $8 \%$ SDS-Polyacrylamide gel $(75 \mu \mathrm{g} / \mathrm{lane})$, incubated with antibodies and detection by ECL methods. (B) Fold-change in BCRP protein expression. Data is represented as mean \pm SD of three independent experiments with statistically significant differences between control and modulator exposed conditions indicated as $* \mathrm{P} \leq 0.05$, ** $\mathrm{P} \leq 0.01$, *** $\mathrm{P} \leq 0.001$ and $* * * * \mathrm{P} \leq 0.0001$.

\section{DISCUSSION}

The regulation of drug disposition into the brain and wider CNS is tightly governed by the impermeable nature of the BBB and BCSFB coupled with an increasingly important complement of drug transporter proteins which tightly regulate the brain and CNS microenvironment $(2,3,7-12,84)$. The expression and impact of BCRP is now clearly recognised at the $\mathrm{BBB}$ and $\mathrm{BCSFB}(39,40,43-$ 45, 85-88). Despite the existence of inhibitors of BCRP which have demonstrated an ability reverse the BCRP efflux phenotype in vitro and, to a limited extent in vivo $(41,42,47-50)$, there yet remains a paucity in the identification of safe and effective modulators of BCRP function.
A novel class of compounds that have gained interest as potential transporter modulation candidates are phytoestrogens, of which flavonoids are the most abundant class. In this context, this study was designed to examine the impact of, primarily, flavonoid exposure on the expression and function of BCRP at the BCSFB using the rat choroid plexus Z310 cells lines which has previously been shown to express P-gp , MRP1 $(80,89)$ and BCRP (37).

This present study has confirmed the expression of BCRP in Z310 cells using reversetranscriptase polymerase chain reaction, with an amplicon product of the expected size (146 base pairs), immunofluorescence confocal microscopy (Figure 2) and western blot analysis (Figure 5A) demonstrating the expression and localisation of BCRP in the rat choroid plexus, consistent with 


\section{(A)}

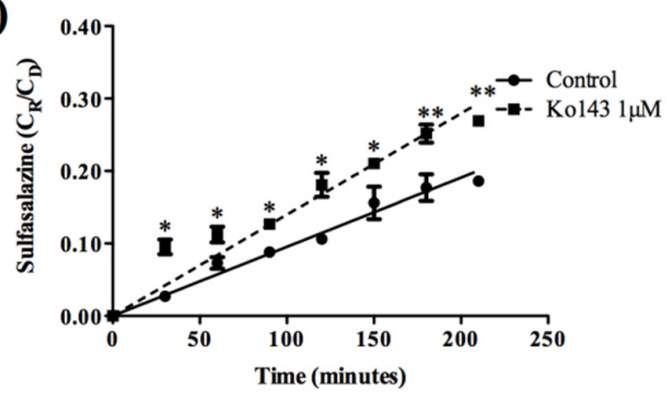

(C)

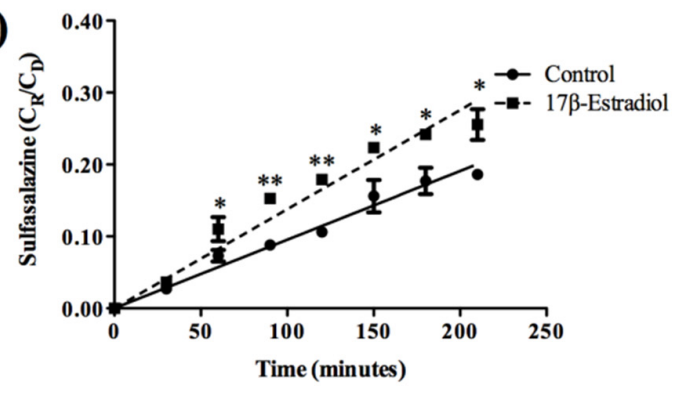

(E)

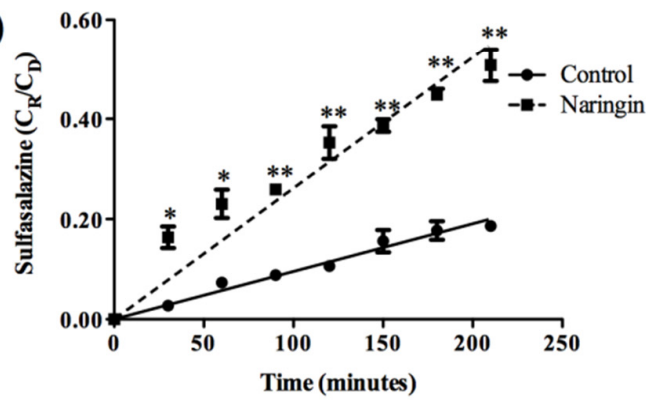

(B)

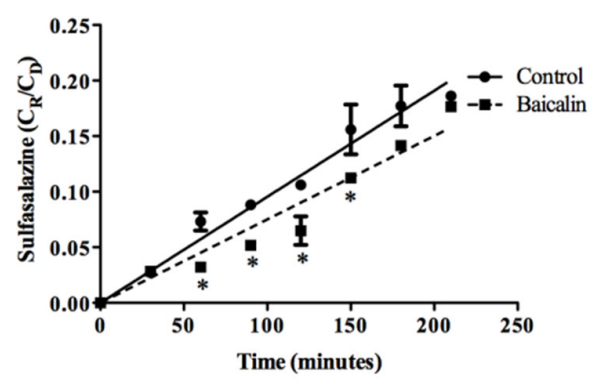

(D)

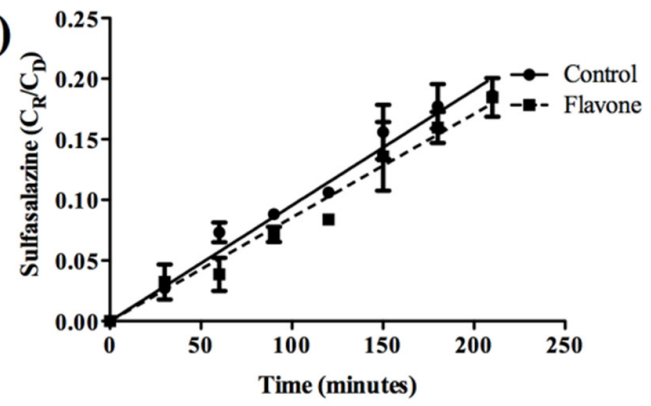

(F)

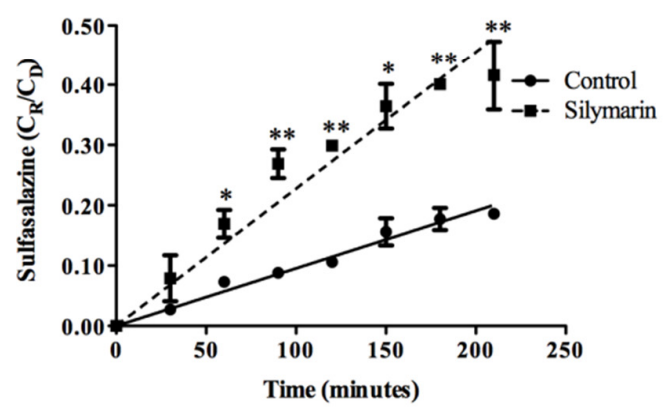

Figure 6. Fraction of sulfasalazine transported across an in vitro BCSFB model in the absence and presence of BCRP modulators. Cells were grown on permeable insert and transport studies were performed on day $8\left(\right.$ TEER $\left.\geq 60 \Omega . \mathrm{cm}^{2}\right)$ using $25 \mu \mathrm{M}$ of modulators. Data is represented as mean $\pm \mathrm{SD}$ of three independent experiments and reported as the ratio of receiver concentration $\left(C_{R}\right)$ and initial donor concentration $\left(C_{D}\right)$. Statistically significant differences between control and modulator exposed conditions are indicated as * $\mathrm{P} \leq 0.05, * * \mathrm{P} \leq 0.01, * * * \mathrm{P} \leq 0.001$ and $* * * * \mathrm{P} \leq 0.0001$.

reported expression and localisation studies in rats (90) (37) and (91). Furthermore BCRP was demonstrated to be functionally active through both a fluorescent substrate (H33342) intracellular accumulation assay in the presence of the known specific BCRP inhibitor (Ko143) (Figure 4) and demonstrated a significantly increased H33342 (P $<0.001)$ intracellular accumulation (2.1 \pm 0.5 fold). Furthermore a monolayer-based permeable insert BCSFB model demonstrated an increased apical-to-basolateral transport of the BCRP substrate sulfasalazine in the presence Ko143 (Figure 6a).

We have, for the first time, demonstrated the cytotoxicity profile of a range of potential BCRP modulators at the BCSFB. For all test compounds studied, the calculated cellular viability $\mathrm{IC}_{50}$ values were in excess of $148 \mu \mathrm{M}$ (Figure 3) and all possessed a dose-dependent cytotoxicity profile.

Whilst there is limited data on the cytotoxicity of flavonoids and their derivatives on CNS-derived tissues, many of the flavonoids employed within this study have been utilised in a range of cell systems with reported cell viabilities and cytotoxicities which concur with our observations and thus may enable limited comparisons to be made for any potential cytotoxic effects (Table 4). 
Table 3. Calculated apparent permeability (apical-to-basolateral) for sulfasalazine in the absence and presence of modulators of BCRP

\begin{tabular}{|c|c|c|}
\hline & \multirow{2}{*}{$\begin{array}{l}\text { Apparent permeability } \\
\mathrm{P}_{\mathrm{app}, \mathrm{AB}}\left(10^{-6} \mathrm{~cm} / \mathrm{s}\right)\end{array}$} & \multirow[b]{2}{*}{$\mathrm{SD}\left(10^{-6} \mathrm{~cm} / \mathrm{s}\right)$} \\
\hline & & \\
\hline Sulfasalazine & 1.32 & 0.12 \\
\hline +Ko143 & $2.11^{* *}$ & 0.09 \\
\hline +Flavone & 1.24 & 0.19 \\
\hline +Naringin & $3.83^{* * *}$ & 0.34 \\
\hline +Silymarin & $3.33^{* * *}$ & 0.61 \\
\hline +Baicalin & 1.10 & 0.08 \\
\hline$+17-\beta$-Estradiol & $2.01^{*}$ & 0.23 \\
\hline \multicolumn{3}{|c|}{$\begin{array}{l}\mathrm{P}_{\mathrm{app}, \mathrm{AB}} \text { was calculated for sulfasalzine alone, in the presence of Ko143 and following pre-incubation for } 24 \text { hours with } \\
\text { modulators. Statistically significant differences between sulfasalazine alone and modulator exposed conditions are } \\
\text { indicated as } * \mathrm{P} \leq 0.05, * * \mathrm{P} \leq 0.01 \text { and } * * * \mathrm{P} \leq 0.001 \text {. }\end{array}$} \\
\hline
\end{tabular}

Despite paucity in flavonoid cytotoxicity data at the BCSFB and other neural tissues, our cellular viability $\mathrm{IC}_{50}$ values and cytotoxicity profiles reported are in agreement with reported observations in a wide range of in vitro cell systems and demonstrate both potentially limited toxicity at sub-100 $\mu \mathrm{M}$ exposure and, in principal, the ability for the flavonoids to penetrate into a range of different cell types.

Interestingly $\alpha$-napthoflavone demonstrates a low $\mathrm{IC}_{50}$ of $1.4 \mu \mathrm{M}$, which in contrast to other compounds used, was significantly lower. Whilst there is a paucity of brain-derived cell viability $\mathrm{IC}_{50}$ values, $\alpha$-napthoflavone is routinely used at sub- $\mu \mathrm{M}$ concentrations as a weak AhR agonist $(0.01 \mu \mathrm{M}-15 \mu \mathrm{M})(69,101)$ and our reported cellular viability IC50 is within this range studied.
The expected in vivo exposure is therefore an important element in attempting to discern any potential in vivo cytotoxicity. In a microdialysis study brain concentrations of naringin were determined in rodents following a $100 \mathrm{mg} / \mathrm{kg}$ dose with a reported $\mathrm{C}_{\max }$ of $0.82 \mu \mathrm{g} / \mathrm{mL}(1.4 \mu \mathrm{M})$ (102). In a further study hesperetin was administrated as an IV bolus dose $(50 \mathrm{mg} / \mathrm{kg})$ to rats and detected in the brain biophase with a $\mathrm{C}_{\max }$ of approximately $0.15 \mu \mathrm{g} / \mathrm{mL}(0.45 \mu \mathrm{M})(103)$. In relation to exposure of flavonoids in the CSF, data is limited but it has been suggested the concentrations are within the range of 1-5 $\mu \mathrm{M}$ (104). Despite this paucity, it is therefore apparent that the expected in vivo exposure would be within below the $\mathrm{IC}_{50}$ of many of the modulators studied.

Table 4. Reported cytotoxicity of flavonoids

\begin{tabular}{lll}
\hline Flavonoid & Extent of toxicity & Cell Line \\
\hline Apigenin & Limited cytotoxicity up to $100 \mu \mathrm{M}$ & HFIIE (92) \\
& Limited cytotoxicity up to $100 \mu \mathrm{M}$ & Rat C6 (92) \\
Biochanin A & $\begin{array}{l}\text { No significant cytotoxicity between 2-100 } \mu \mathrm{M} \text { during a 72-hour } \\
\text { exposure }\end{array}$ & MCF-10A and NIH-3T3 (93) \\
& Dose-dependent cytotoxicity & SK-BR-3 (94) \\
& No toxicity up to $100 \mu \mathrm{M}$ & RAW264.7 (94) \\
& $\mathrm{IC}_{50}=50 \mu \mathrm{M}$ & HT-9 (94) \\
Fistein & $27.6 \%$ reduction in viability at $120 \mu \mathrm{M}$ for 24 hours & COLO205 (95) \\
Hesperidin & $\mathrm{IC}_{50}=195 \mu \mathrm{M}$ & Caco-2 (96) \\
& $\mathrm{IC}_{50}=230 \mu \mathrm{M}$ & CEM/ADR5000 (96) \\
& $\mathrm{IC}_{50}=95 \mu \mathrm{M}$ & CCRF_CEM (96) \\
& Limited cytotoxicity at $100 \mu \mathrm{M}$ with a viability of 53\% & SNU-668 (97) \\
& $\mathrm{IC}_{50}=150 \mu \mathrm{M}$ & MSTO-211H (98) \\
Quercetin & No significant cytotoxicity between 20-80 $\mu \mathrm{M}$ & RAW264.7 cells (99) \\
Rutin & Limited cytotoxicity up to $270 \mu \mathrm{M}$ with a viability of $80 \%$ at $810 \mu \mathrm{M}$ & HTC (100) \\
\hline
\end{tabular}


BCRP has a highly diverse range of substrates and has been extensively reviewed elsewhere (105-107). In this study we chose to utilise a commonly used probe substrate for BCRP, $\mathrm{H} 33342$ (108, 109), and take advantage of its fluorescent properties to assess the intracellular accumulation of $\mathrm{H} 33342$ (110) Using the known specific inhibitor for BCRP, Ko143 (43, 111), our accumulation results demonstrated a highly significant $(\mathrm{P}<0.001)$ increase in the intracellular accumulation of $\mathrm{H} 33342$ (Figure 4), indicating the specific inhibition of BCRP-associated $\mathrm{H} 33342$ efflux and concurring with other reports demonstrating the specific nature of BCRP inhibition when using $\operatorname{Kol} 43$ (43, 111). when compared to control cells, the exposure of $25 \mu \mathrm{M}$ modulators to Z310 cells for 24 hours resulted in a statistically significant increase in $\mathrm{H} 33342$ accumulation $(\mathrm{P} \leq 0.0001)$ for all modulators studied. Furthermore, when compared to Ko143 a range of flavonoids demonstrated significantly increased intracellular accumulation of $\mathrm{H} 33342$ (P $<0.05$ : silymarin; $\mathrm{P}<0.01$ : biochanin $\mathrm{A}$, and quercetin; $\mathrm{P}<0.001$ : chrysin and rutin). Although baicalin, fisetin and $\alpha$-napthoflavone also demonstrated significantly increased intracellular accumulation of $\mathrm{H} 33342$, this should be viewed with caution when considering the inherent fluorescence emission observed overlapping with that of H33342. Furthermore 17- $\beta$-estradiol, a known potent BCRP downregulator (77), also demonstrated significantly increased intracellular accumulation of $\mathrm{H} 33342$

As the mechanism of inhibition is not a direct competitive one, due to the pre-incubation period followed by a wash-out period in fresh incubation media, these effects suggest the modulators studied are able to impart an effect that is potentially unrelated to an effect on the substrate binding sites. To this end, we undertook a western blotting procedure to asses any discernible change in BCRP protein expression following similar 24 hour incubation with modulators.

Our results highlighted that out of the 18 modulators studied, only 8 showed a statistically significant change in BCRP protein expression, with baicalin, hesperidin and flavone showing a BCRP up-regulation effect and naringin, quercetin and silymarin showing a downregulation effect (Figure 5). Of the nonphytoestrogenic compounds the positive control used within this study (17- $\beta$-estradiol) demsontrated the expected trend of downregulation of BCRP. This down regulation could be the result of interference with 17- $\beta$-estradiol signalling pathways by $\mathrm{ER} \alpha$ and $\mathrm{ER} \beta$. Imai et al
(2005) (112) demonstrated that 17- $\beta$-estradiol significantly reduced the expression of BCRP in MCF-7 cells at low nanomolar concentrations (3 $\mathrm{nmol} / \mathrm{L})$ for 1,2 and 4 days (2-,5- and 10-fold down regulation respectively). Furthermore, Hartz et al (2010) (77) found that the protein expression of BCRP was down regulated in the presence of $17-\beta$-estradiol in rat brain capillaries.

Of note is a 2.5 -fold or greater change in BCRP expression when exposed to flavone, baicalin and hesperidin and a 0.16-0.49 fold decrease in BCRP expression when exposed to naringin, silymarin, quercetin and $17-\beta$ estradiol (Figure 5).

In addressing the observed changes in BCRP expression, a study by Ebert et al (66) reported that $25 \mu \mathrm{M}$ and $50 \mu \mathrm{M}$ quercetin increased BCRP protein expression in human intestine carcinoma cells (Caco-2) by 2.6 and 5.3-fold following a 72hour incubation. On an mRNA level Ebert et al (66) also demonstrated a 19-37-fold increase in BCRP mRNA when exposed to $50 \mu \mathrm{M}$ of chrysin, quercetin, resveratrol and flavone.

Similarly, our studies demonstrated a significant down-regulation of BCRP expression with silymarin, but in Caco-2 cells Ebert et al (66) demonstrated increased expression. Modulators, specifically flavonoids, have therefore been demonstrated to have the capacity to alter BCRP expression at the protein levels, although the differences in modulation between our study and those reported by Ebert et al (66) in Caco-2 cells may signify cell specificity in the change in protein expression and/or may suggest a timedependant effect.

To be in a position to gauge the functional consequences of any change in BCRP expression we conducted a transport study using a permeable insert system. The assay was developed by preincubating cells, grown on a permeable insert system, for 24 hours with the modulator followed by a wash-out period and monitoring the transport of the BCRP substrate sulfasalazine (in the absence of any modulators) for the duration of the transport study. We chose the BCRP specific inhibitor Ko143, and the modulators baicalin, 17$\beta$ - estradiol, flavone, naringin and silymarin to investigate and sulfasalazine as known BCRP substrate $(114,115)$. Our initial studies were conducted with Ko143 and we observed a statistically significant increase in apical-tobasolateral sulfasalazine flux across all time points when compared to control inserts (Figure 6a) concurring with the presence of BCRP protein as indicated in the western blot analysis (Figure 5a) and the functional direction of efflux transport 
(basolateral-to-apical) and hence the inhibition of BCRP (increased apical-to-basolateral flux) at the BCSFB.

Baicalin demonstrated a significant increase in protein expression ( $2.42 \pm 0.19$ fold) and was therefore chosen as a potential up-regulator of BCRP expression. In the transport studies a significant decrease $(\mathrm{P}<0.05)$ in apical-tobasolateral flux (approximately 10\%) for a portion of the assay period (60-150 minutes) was observed, demonstrating the increasing basolateral-to-apical transport of sulfasalazine and hence diminishing the overall apical-tobasolateral flux. However, when examining the impact of flavone on BCRP, no significant differences were observed in apical-to-basolateral flux for the duration of the study. This was surprising as flavone demonstrated the greatest up-regulation of BCRP protein in western blots (Figure 5) and may indicate time-dependant protein decay following the up-regulation phenomena.

When investigating the impact of the downregulators $17-\beta$-estradiol, naringin and silymarin, we observed statistically significant differences across all time-points with a $8 \%, 40 \%$ and $26 \%$ increase in sulfasalazine transport, for 17- $\beta$ estradiol (Figure 6c), naringin (Figure 6e) and silymarin (Figure 6f). This was also translated into similar significant increases in the $\mathrm{P}_{\mathrm{app}, \mathrm{AB}}$ for these compounds (Table 3).

Of interest is the translational effect of downregulation in BCRP protein when exposed to naringin and silymarin $(0.16 \pm 0.07$ fold and 0.22 \pm 0.09 fold change in protein expression, respectively, figure 5) and the resultant effect on 'CSF-to-blood' sulfasalazine transport where $\mathrm{P}_{\text {app, } A \mathrm{BB}}$ for naringin and silymarin was increased by 2.9 - and 2.5 -fold, respectively. This effect clearly highlights the potential impact of prolonged exposure of flavonoids to BCRP may have on substrate transport and how this may influence the disposition of transporter substrate at the BCSFB and wider CNS.

Given the paucity in reported data on the interaction of flavonoids of BCRP expression/function at the BCSFB, our western blot and functional transport studies concur with other similar results from Hartz et al (2010) (77) who demonstrated that $17-\beta$-estradiol is able to down-regulate $\mathrm{BCRP}$ at the $\mathrm{BBB}$.

The question remains however, how effective will flavonoids be in vivo and will they reach sufficient levels to initiate such a response? The dietary intake of flavonoids provides the body with flavonoids which exist predominantly in planta as glycoside conjugates and which often possess limited absorption into the systemic circulation (116). Upon contact with lactase phloridzin hydrolase (LPH) at the brush border of the enterocyte, the aglycone is formed and is absorbed by passive diffusion (117). The final form found in the circulation is often the sulfate, glucuronide and/or methylated metabolites as a result of the action of sulfotransferases (SULT), uridine-5'-diphosphate glucuronosyltransferases (UGTs) and catechol- $O$-methyltransferases (COMT) (116). It is therefore unlikely that the conjugated form of the flavonoids would naturally be capable of crossing the BCSFB or BBB.

Numerous studies have demonstrated that the aglycone is capable of transferring across the BBB. Naringenin and hesperetin $(30 \mu \mathrm{M})$ have been demonstrated to be able to penetrate the BBB in two brain endothelial cell lines (mouse b.END5 and rat RBE4) and an in vitro model of the BBB (ECV304 cells co-cultured with C6 glioma cells), with a significant level of uptake into b.END5 and RBE4 cells (hesperetin: 140 and $146 \mathrm{ng} / \mathrm{mg}$ protein, respectively; naringenin:177 and $127 \mathrm{ng} / \mathrm{mg}$ protein, respectively) (118), with the aglycone form of flavonoids demonstrating significantly greater penetration across the BBB compared to the conjugated form [aglycone: naringenin $\left(\mathrm{P}_{\text {app }}=350 \mathrm{~nm} / \mathrm{s}\right)$ and hesperetin $\left(\mathrm{P}_{\text {app }}\right.$ $=290 \mathrm{~nm} / \mathrm{s})$; conjugated $\left.\left(\mathrm{P}_{\text {app }}=113-182 \mathrm{~nm} / \mathrm{s}\right)\right]$. In a further study the aglycone form of $\left[{ }^{3} \mathrm{H}\right]-$ naringenin was able to be detected in most brains regions using in situ perfusion studies in rats (119).

Furthermore, in an in vivo study by RangelOrdonez et al (2010) (120), a standard extract of Ginkgo biloba (extract EGb761) was given to rats at a single dose of $600 \mathrm{mg} / \mathrm{kg}$. Following this dose, only kaempferol and isorhamnetin were detected in brain tissues (293 ng/g brain). Furthermore, high concentrations of quercetin were detected in the hippocampus, stratum and cerebellum, with levels exceed $1000 \mathrm{ng} / \mathrm{g}$ brain protein. Peng et al., (1998) (121) demonstrated that the aglycone form of naringenin was detected in the cerebral cortex of rats following an IV bolus dose.

It is clear that the aglycone form is capable of penetrating the BBB and therefore the delivery of such aglycone (and unconjugated) flavonoids are important. This has been demonstrated through approaches involved nanoparticulate delivery systems encapsulating often poorly soluble aglycone forms of flavonoids (Table 5).

It is therefore envisaged that, at the BCSFB, the aglycone form of flavonoids would be able to 
gain access to the chorodial epithelial cells to elicit a modulator effect on BCRP expression, with the potential benefit of a nanoparticulate carrier system enhancing the retention of the aglycone form within the circulation.

Our studies have demonstrated that flavonoids can be utilised as potential modulators of BCRP function at the BCSFB, but the mechanism of the observed changes are important in the understanding of how flavonoids can be adapted to be useful. BCRP has been reported to be modulated by a number of nuclear receptors including peroxisome proliferator-activated receptor $\alpha$ (PPAR $\alpha)$ in human immortalised hCMEC/D3 cells $(132,133)$, nuclear factor $\mathrm{kB}$ (NF-kB) in primary (134) and immortalised (hCMEC/D3) (135) brain endothelial cells, pregnane $\mathrm{X}$ receptor (PXR) and constitutive androstane receptor (CAR) $(136,137)$, esteogen receptors in rodent brain capillaries (77) (138) and recently the aryl hydrocarbon receptor (AhR) (66, 139-142).

The regulation of BCRP has clearly been demonstrated in a range of tissues but a complete understanding of its role at neural tissues is still lacking. The exact mechanism by which BCRP regulation is precisely controlled therefore warrants further study, particularly considering there is evidence to suggest that flavonoids are capable of permeating the $\mathrm{BBB}$ and/or the BCSFB, for example quercetin $(119,143)$; catechin and epicatechin (144); hesperetin, naringenin, epicatechin and their glucuronides (118) and kaempferol and isorhamnetin (120) are capable of permeating the $\mathrm{BBB}$ and/or the BCSFB and therefore have the potential to interact with any of these regulatory elements.
A potentially novel application of the modulation of the regulatory control of drug transporter proteins was recently reported by Hartz et al (2010) (145) using an Alzheimer's disease rodent model. Using this model the expression of P-glycoprotein at the BBB was found to be reduced, leading to the accumulation of the neurotoxic peptide $\beta$-amyloid in neural tissues. Hartz et al (2010) (145) was able to demonstrate that the restoration of P-glycoprotein expression through, PXR activation, resulted in the reduction of brain levels of $\beta$-amyloid. Thus, further work is required to ascertain the exact mechanism of regulatory control of BCRP during prolonged exposure to flavonoid and how this could be adapted to enhance the distribution of therapeutic agents into the brain and wider CNS.

\section{CONCLUSION}

We have, for the first time, successfully demonstrated the ability of flavonoids to modulate the protein expression of BCRP at the BCSFB. Furthermore, our studies have demonstrated that flavonoids are generally expected to show limited cytotoxicity at the BCSFB with naringin and silymarin possessing the characteristics of potent down-regulators of $\mathrm{BCRP}$ protein at the BCSFB which translated into a significant increase in CSF-to-blood passage of drug, potentially providing an opportunity to alter the CNS disposition patterns of drugs. It is important to further elucidate the mechanism of such regulatory changes, whether genomic via nuclear receptors or non-genomic in nature, and furthermore the in vivo impact on BCRP substrate transports the BCSFB.

Table 5. Encapsualtion and targeting of phytoestrogens to the CNS

\begin{tabular}{lll}
\hline Phytoesteogen nanoparticles & $\begin{array}{l}\text { Payload } \\
\text { Quercetin and catechin (122) } \\
\text { Quercetin and etoposide (123) } \\
\text { Quercetin (124) }\end{array}$ & $\begin{array}{l}\text { Species } \\
\text { In vitro }\end{array}$ \\
$\begin{array}{l}\text { Nanographene oxide } \\
\text { Non-phytoestrogen nanoparticles }\end{array}$ & $\begin{array}{l}\text { Rats } \\
\text { In vitro }\end{array}$ \\
PLA (125) & \\
Chitosan (126) & Rats \\
Albumin nanoparticles (127) & Rats \\
Functionalised nanoparticles & Mice \\
Gelatin-soloxane TAT-peptide (128, 129) & \\
Ritonavir loaded TAT-conjugated PLA nanoparticles (130) & Mice \\
Transferrin anchored pegylated albumin nanoparticles (131) & Mice \\
\hline
\end{tabular}




\section{ACKNOWLEDGEMENTS}

The authors would like to thank Dr. Wei Zheng for providing Z310 cell lines.

\section{REFERENCES}

1. Strazielle N, Khuth ST, Ghersi-Egea J-F. Detoxification systems, passive and specific transport for drugs at the blood-CSF barrier in normal and pathological situations. Advanced Drug Delivery Reviews. 2004;56(12):1717-40.

2. Smith DE, Johanson CE, Keep RF. Peptide and peptide analog transport systems at the bloodCSF barrier. Advanced Drug Delivery Reviews. 2004;56(12):1765-91.

3. Szmydynger-Chodobska J, Chodobski A, Johanson CE. Postnatal developmental changes in blood flow to choroid plexuses and cerebral cortex of the rat. The American journal of physiology. 1994;266(5 Pt 2):R1488-92.

4. Emerich DF, Skinner SJ, Borlongan CV, Vasconcellos AV, Thanos CG. The choroid plexus in the rise, fall and repair of the brain. BioEssays : news and reviews in molecular, cellular and developmental biology. 2005;27(3):262-74.

5. Chodobski A, Szmydynger-Chodobska J. Choroid plexus: target for polypeptides and site of their synthesis. Microscopy research and technique. 2001;52(1):65-82.

6. Faraci FM, Kinzenbaw D, Heistad DD. Effect of endogenous vasopressin on blood flow to choroid plexus during hypoxia and intracranial hypertension. The American journal of physiology. 1994;266(2 Pt 2):H393-8.

7. Wright EM. Transport processes in the formation of the cerebrospinal fluid. Reviews of physiology, biochemistry and pharmacology. 1978;83:3-34.

8. Ghersi-Egea J-F, Sugiyama Y. Drug transfer in the choroid plexus. Multiplicity and substrate specificities of transporters. Advanced Drug Delivery Reviews. 2004;56(12):1693-4.

9. Siegel GJ, Agranoff BW, Albers RW. Basic Neurochemistry: Molecular, Cellular and Medical Aspects. 6th edition ed. Philadelphia: Philadelphia: Lippincott-Raven; 1999.

10. Johanson CE. Choroid Plexus. New York, USA: Elsevier Science; 1999. 384-7 p.

11. Emerich DF, Skinner SJM, Borlongan CV, Vasconcellos AV, Thanos CG. The choroid plexus in the rise, fall and repair of the brain. BioEassys. 2005;27(3):262-74.

12. Redzic ZB, Segal MB. The structure of the choroid plexus and the physiology of the choroid plexus epithelium. Advanced Drug Delivery Reviews. 2004;56(12):1695-716.

13. Spector R, Johanson CE. Sustained choroid plexus function in human elderly and
Alzheimer's disease patients. Fluids Barriers CNS. 2013;10(1):28.

14. Ek CJ, Wong A, Liddelow SA, Johansson PA, Dziegielewska KM, Saunders NR. Efflux mechanisms at the developing brain barriers: $\mathrm{ABC}$-transporters in the fetal and postnatal rat. Toxicology Letters. 2010;197(1):51-9.

15. Rao VV, Dahlheimer JL, Bardgett ME, Snyder AZ, Finch RA, Sartorelli AC, et al. Choroid plexus epithelial expression of MDR1 P glycoprotein and multidrug resistanceassociated protein contribute to the bloodcerebrospinal-fluid drug-permeability barrier. Proceedings of the National Academy of Sciences of the United States of America. 1999;96(7):3900-5.

16. Kusuhara H, Sugiyama Y. Efflux transport systems for drugs at the blood-brain barrier and blood-cerebrospinal fluid barrier (Part 2). Drug discovery today. 2001;6(4):206-12.

17. Flens MJ, Zaman G, Van der Valk P, Izquierdo MA, Schroeijers AB, Scheffer GL, et al. Tissue distribution of the multidrug resistance protein. The American journal of pathology. 1996;148(4):1237.

18. Yan R, Taylor EM. Neotrofin is transported out of brain by a saturable mechanism: possible involvement of multidrug resistance and monocarboxylic acid transporters. Drug metabolism and disposition: the biological fate of chemicals. 2002;30(5):513-8.

19. Doyle LA, Yang W, Abruzzo LV, Krogmann T, Gao Y, Rishi AK, et al. A multidrug resistance transporter from human MCF-7 breast cancer cells. Proceedings of the National Academy of Sciences of the United States of America. 1998;95(26): 15665-70.

20. Allikmets R, Schriml LM, Hutchinson A, Romano-Spica V, Dean M. A human placentaspecific ATP-binding cassette gene (ABCP) on chromosome 4q22 that is involved in multidrug resistance. Cancer research. 1998;58(23):53379.

21. Miyake K, Mickley L, Litman T, Zhan Z, Robey $\mathrm{R}$, Cristensen B, et al. Molecular cloning of cDNAs which are highly overexpressed in mitoxantrone-resistant cells: demonstration of homology to $\mathrm{ABC}$ transport genes. Cancer research. 1999;59(1):8-13.

22. Wulf GG, Luo KL, Jackson KA, Brenner MK, Goodell MA. Cells of the hepatic side population contribute to liver regeneration and can be replenished with bone marrow stem cells. Haematologica. 2003;88(4):368-78.

23. Summer R, Kotton DN, Sun X, Ma B, Fitzsimmons K, Fine A. Side population cells and Bcrp1 expression in lung. American journal of physiology Lung cellular and molecular physiology. 2003;285(1):L97-104.

24. Lin KK, Goodell MA. Detection of hematopoietic stem cells by flow cytometry. Methods in cell biology. 2011;103:21-30. 
25. Maliepaard M, Scheffer GL, Faneyte IF, van Gastelen MA, Pijnenborg AC, Schinkel AH, et al. Subcellular localization and distribution of the breast cancer resistance protein transporter in normal human tissues. Cancer research. 2001;61(8):3458-64.

26. Kitano $\mathrm{T}$, Iizasa $\mathrm{H}$, Hwang IW, Hirose $\mathrm{Y}$, Morita $\mathrm{T}$, Maeda $\mathrm{T}$, et al. Conditionally immortalized syncytiotrophoblast cell lines as new tools for study of the blood-placenta barrier. Biological \& pharmaceutical bulletin. 2004;27(6):753-9.

27. Cooray HC, Blackmore CG, Maskell L, Barrand MA. Localisation of breast cancer resistance protein in microvessel endothelium of human brain. Neuroreport. 2002;13(16):2059-63.

28. Bart J, Hollema H, Groen HJ, de Vries EG, Hendrikse NH, Sleijfer DT, et al. The distribution of drug-efflux pumps, P-gp, BCRP, MRP1 and MRP2, in the normal blood-testis barrier and in primary testicular tumours. European journal of cancer. 2004;40(14):206470.

29. Asashima T, Hori S, Ohtsuki S, Tachikawa M, Watanabe M, Mukai C, et al. ATP-binding cassette transporter G2 mediates the efflux of phototoxins on the luminal membrane of retinal capillary endothelial cells. Pharmaceutical research. 2006;23(6):1235-42.

30. de Vries NA, Zhao J, Kroon E, Buckle T, Beijnen JH, van Tellingen O. P-glycoprotein and breast cancer resistance protein: two dominant transporters working together in limiting the brain penetration of topotecan. Clinical cancer research : an official journal of the American Association for Cancer Research. 2007;13(21):6440-9.

31. Wanek T, Kuntner C, Bankstahl JP, Mairinger S, Bankstahl M, Stanek J, et al. A novel PET protocol for visualization of breast cancer resistance protein function at the blood-brain barrier. Journal of cerebral blood flow and metabolism : official journal of the International Society of Cerebral Blood Flow and Metabolism. 2012;32(11):2002-11.

32. Zhang MR, Kumata K, Hatori A, Takai N, Toyohara J, Yamasaki T, et al. [11C]Gefitinib ([11c]Iressa): radiosynthesis, in vitro uptake, and in vivo imaging of intact murine fibrosarcoma. Molecular imaging and biology : MIB : the official publication of the Academy of Molecular Imaging. 2010;12(2):181-91.

33. Kawamura K, Yamasaki T, Yui J, Hatori A, Konno F, Kumata K, et al. In vivo evaluation of P-glycoprotein and breast cancer resistance protein modulation in the brain using [(11)C]gefitinib. Nuclear medicine and biology. 2009;36(3):239-46.

34. Asakawa C, Ogawa M, Kumata K, Fujinaga M, Kato K, Yamasaki T, et al. [11C]sorafenib: radiosynthesis and preliminary $\mathrm{PET}$ study of brain uptake in P-gp/Bcrp knockout mice.
Bioorganic \& medicinal chemistry letters. 2011;21(8):2220-3.

35. Shimoda Y, Yui J, Fujinaga M, Xie L, Kumata $\mathrm{K}$, Ogawa $\mathrm{M}$, et al. [(11)C-carbonyl]CEP32496: radiosynthesis, biodistribution and PET study of brain uptake in P-gp/BCRP knockout mice. Bioorganic \& medicinal chemistry letters. 2014;24(15):3574-7.

36. Tachikawa M, Watanabe M, Hori S, Fukaya M, Ohtsuki S, Asashima T, et al. Distinct spatiotemporal expression of $\mathrm{ABCA}$ and $\mathrm{ABCG}$ transporters in the developing and adult mouse brain. Journal of neurochemistry. 2005;95(1):294-304.

37. Halwachs S, Lakoma C, Schäfer I, Seibel P, Honscha W. The antiepileptic drugs phenobarbital and carbamazepine reduce transport of methotrexate in rat choroid plexus by down-regulation of the reduced folate carrier. Molecular Pharmacology. 2011;80(4):621-9.

38. Zhuang $\mathrm{Y}$, Fraga $\mathrm{CH}$, Hubbard $\mathrm{KE}$, Hagedorn N, Panetta JC, Waters CM, et al. Topotecan central nervous system penetration is altered by a tyrosine kinase inhibitor. Cancer research. 2006;66(23):11305-13.

39. Suzuki H, Sugiyama Y. Role of metabolic enzymes and efflux transporters in the absorption of drugs from the small intestine. European journal of pharmaceutical sciences. 2000;12(1):3-12.

40. Huber R, Hartmann M, Bliesath H, Luhmann R, Steinijans VW, Zech K. Pharmacokinetics of pantoprazole in man. International journal of clinical pharmacology and therapeutics. 1996;34(1 Suppl):S7-16.

41. de Bruin M, Miyake K, Litman T, Robey R, Bates SE. Reversal of resistance by GF120918 in cell lines expressing the $\mathrm{ABC}$ halftransporter, MXR. Cancer letters. 1999;146(2):117-26.

42. Rabindran SK, Ross DD, Doyle LA, Yang W, Greenberger LM. Fumitremorgin C reverses multidrug resistance in cells transfected with the breast cancer resistance protein. Cancer research. 2000;60(1):47-50.

43. Allen JD, van Loevezijn A, Lakhai JM, van der Valk M, van Tellingen O, Reid G, et al. Potent and specific inhibition of the breast cancer resistance protein multidrug transporter in vitro and in mouse intestine by a novel analogue of fumitremorgin C. Mol Cancer Ther. 2002;1(6):417-25.

44. Breedveld P, Beijnen JH, Schellens JH. Use of P-glycoprotein and BCRP inhibitors to improve oral bioavailability and CNS penetration of anticancer drugs. Trends in pharmacological sciences. 2006;27(1):17-24.

45. Lagas JS, van Waterschoot RA, van Tilburg VA, Hillebrand MJ, Lankheet N, Rosing H, et al. Brain accumulation of dasatinib is restricted by P-glycoprotein $(\mathrm{ABCB} 1)$ and breast cancer resistance protein $(\mathrm{ABCG})$ and can be 
enhanced by elacridar treatment. Clinical cancer research : an official journal of the American Association for Cancer Research. 2009;15(7):2344-51.

46. Kuhnau J. The flavonoids. A class of semiessential food components: their role in human nutrition. World review of nutrition and dietetics. 1976;24:117-91.

47. Formica JV, Regelson W. Review of the biology of Quercetin and related bioflavonoids. Food and chemical toxicology : an international journal published for the British Industrial Biological Research Association. 1995;33(12):1061-80.

48. Ferrandiz ML, Alcaraz MJ. Anti-inflammatory activity and inhibition of arachidonic acid metabolism by flavonoids. Agents and actions. 1991;32(3-4):283-8.

49. Lou FQ, Zhang MF, Zhang XG, Liu JM, Yuan WL. A study on tea-pigment in prevention of atherosclerosis. Chinese medical journal. 1989;102(8):579-83.

50. Osman HE, Maalej N, Shanmuganayagam D, Folts JD. Grape juice but not orange or grapefruit juice inhibits platelet activity in dogs and monkeys (Macaca fasciularis). J Nutr. 1998;128(12):2307-12.

51. Lai CS, Li S, Miyauchi Y, Suzawa M, Ho CT, Pan MH. Potent anti-cancer effects of citrus peel flavonoids in human prostate xenograft tumors. Food \& function. 2013;4(6):944-9.

52. Khachatoorian R, Arumugaswami V, Raychaudhuri S, Yeh GK, Maloney EM, Wang $\mathrm{J}$, et al. Divergent antiviral effects of bioflavonoids on the hepatitis $\mathrm{C}$ virus life cycle. Virology. 2012;433(2):346-55.

53. Nijveldt RJ, van Nood E, van Hoorn DE, Boelens PG, van Norren K, van Leeuwen PA. Flavonoids: a review of probable mechanisms of action and potential applications. The American journal of clinical nutrition. 2001;74(4):418-25.

54. Lattrich C, Lubig J, Springwald A, Goerse R, Ortmann O, Treeck O. Additive effects of trastuzumab and genistein on human breast cancer cells. Anticancer Drugs. 2011;22(3):25361.

55. Pick A, Müller H, Mayer R, Haenisch B, Pajeva IK, Weigt $M$, et al. Structure-activity relationships of flavonoids as inhibitors of breast cancer resistance protein (BCRP). Bioorganic \& Medicinal Chemistry. 2011;19(6):2090-102.

56. Zhang S, Yang X, Morris ME. Flavonoids are inhibitors of breast cancer resistance protein (ABCG2)-mediated transport. Mol Pharmacol. 2004;65(5):1208-16.

57. Zhang S, Morris ME. Effect of the flavonoids biochanin A and silymarin on the Pglycoprotein-mediated transport of digoxin and vinblastine in human intestinal Caco-2 cells. Pharmaceutical research. 2003;20(8):1184-91.
58. Rosenberg RS, Grass L, Jenkins DJ, Kendall $\mathrm{CW}$, EP D. Modulation of androgen and progesterone receptors by phytochemicals in breast cancer cell lines. . Biochemical and Biophysical Research Communications 1998;248(3):935-9.

59. Peng IW, Kuo SM. Flavonoid structure affects the inhibition of lipid peroxidation in Caco-2 intestinal cells at physiological concentrations. J Nutr. 2003;133(7):2184-7.

60. Tian XJ, Yang XW, Yang X, Wang K. Studies of intestinal permeability of 36 flavonoids using Caco-2 cell monolayer model. International journal of pharmaceutics. 2009;367(1-2):58-64.

61. Murota K, Shimizu S, Miyamoto S, Izumi T, Obata A, Kikuchi M, et al. Unique uptake and transport of isoflavone aglycones by human intestinal caco-2 cells: comparison of isoflavonoids and flavonoids. $\mathrm{J}$ Nutr. 2002;132(7):1956-61.

62. Xia CQ, Liu N, Yang D, Miwa G, Gan LS. Expression, localization, and functional characteristics of breast cancer resistance protein in Caco-2 cells. Drug Metabolism and Disposition. 2005;33(5):637-43.

63. Zheng W, Zhao Q. Establishment and characterization of an immortalized Z310 choroidal epithelial cell line from murine choroid plexus. Brain research. 2002;958(2):371-80.

64. Kusuhara H, Furuie H, Inano A, Sunagawa A, Yamada S, Wu C, et al. Pharmacokinetic interaction study of sulphasalazine in healthy subjects and the impact of curcumin as an in vivo inhibitor of BCRP. British journal of pharmacology. 2012;166(6):1793-803.

65. Shukla S, Zaher H, Hartz A, Bauer B, Ware JA, Ambudkar SV. Curcumin inhibits the activity of ABCG2/BCRP1, a multidrug resistance-linked $\mathrm{ABC}$ drug transporter in mice. Pharmaceutical research. 2009;26(2):480-7.

66. Ebert B, Seidel A, Lampen A. Phytochemicals induce breast cancer resistance protein in Caco2 cells and enhance the transport of benzo[a]pyrene-3-sulfate. Toxicological sciences : an official journal of the Society of Toxicology. 2007;96(2):227-36.

67. Zhang S, Yang X, Morris ME. Combined effects of multiple flavonoids on breast cancer resistance protein (ABCG2)-mediated transport. Pharmaceutical research. 2004;21(7):1263-73.

68. Zhang L, Lin G, Kovacs B, Jani M, Krajcsi P, Zuo Z. Mechanistic study on the intestinal absorption and disposition of baicalein. European journal of pharmaceutical sciences : official journal of the European Federation for Pharmaceutical Sciences. 2007;31(3-4):221-31.

69. Santostefano M, Merchant M, Arellano L, Morrison V, Denison MS, Safe S. alphaNaphthoflavone-induced CYP1A1 gene expression and cytosolic aryl hydrocarbon 
receptor transformation. Mol Pharmacol. 1993;43(2):200-6.

70. Murray IA, Flaveny CA, DiNatale BC, Chairo CR, Schroeder JC, Kusnadi A, et al. Antagonism of aryl hydrocarbon receptor signaling by $6,2^{\prime}, 4^{\prime}$-trimethoxyflavone. The Journal of pharmacology and experimental therapeutics. 2010;332(1):135-44.

71. Yoshikawa M, Ikegami Y, Sano K, Yoshida H, Mitomo H, Sawada S, et al. Transport of SN-38 by the wild type of human $\mathrm{ABC}$ transporter ABCG2 and its inhibition by quercetin, a natural flavonoid. Journal of experimental therapeutics \& oncology. 2004;4(1):25-35.

72. Cooray HC, Janvilisri T, van Veen HW, Hladky $\mathrm{SB}$, Barrand MA. Interaction of the breast cancer resistance protein with plant polyphenols. Biochemical and biophysical research communications. 2004;317(1):269-75.

73. Casper RF, Quesne M, Rogers IM, Shirota T, Jolivet A, Milgrom E, et al. Resveratrol has antagonist activity on the aryl hydrocarbon receptor: implications for prevention of dioxin toxicity. Mol Pharmacol. 1999;56(4):784-90.

74. Tamaki H, Satoh H, Hori S, Ohtani H, Sawada Y. Inhibitory effects of herbal extracts on breast cancer resistance protein (BCRP) and structureinhibitory potency relationship of isoflavonoids. Drug metabolism and pharmacokinetics. 2010;25(2):170-9.

75. Zhang S, Yang X, Coburn RA, Morris ME. Structure activity relationships and quantitative structure activity relationships for the flavonoidmediated inhibition of breast cancer resistance protein. Biochemical pharmacology. 2005;70(4):627-39.

76. Nebert DW, Roe AL, Dieter MZ, Solis WA, Yang Y, Dalton TP. Role of the aromatic hydrocarbon receptor and $[\mathrm{Ah}]$ gene battery in the oxidative stress response, cell cycle control, and apoptosis. Biochemical pharmacology. 2000;59(1):65-85.

77. Hartz AM, Mahringer A, Miller DS, Bauer B. 17-beta-Estradiol: a powerful modulator of blood-brain barrier BCRP activity. Journal of cerebral blood flow and metabolism : official journal of the International Society of Cerebral Blood Flow and Metabolism. 2010;30(10):174255.

78. Shi LZ, Zheng W. Establishment of an in vitro brain barrier epithelial transport system for pharmacological and toxicological study. Brain research. 2005;1057(1-2):37-48.

79. Zheng W, Lu YM, Lu GY, Zhao Q, Cheung O, Blaner WS. Transthyretin, thyroxine, and retinol-binding protein in human cerebrospinal fluid: effect of lead exposure. Toxicological sciences : an official journal of the Society of Toxicology. 2001;61(1):107-14.

80. Shi LZ, Li GJ, Wang S, Zheng W. Use of Z310 cells as an in vitro blood-cerebrospinal fluid barrier model: tight junction proteins and transport properties. Toxicology in vitro. 2008;22(1):190-9.

81. Krzyzankova M, Mertsch S, Koos B, Jeibmann A, Kruse A, Kordes U, et al. Loss of TP53 expression in immortalized choroid plexus epithelial cells results in increased resistance to anticancer agents. J Neurooncol. 2012;109(3):449-55.

82. Hu HH, Bian YC, Liu Y, Sheng R, Jiang HD, $\mathrm{Yu}$ LS, et al. Evaluation of blood-brain barrier and blood-cerebrospinal fluid barrier permeability of 2-phenoxy-indan-1-one derivatives using in vitro cell models. International journal of pharmaceutics. 2014;460(1-2):101-7.

83. Fu X, Zeng A, Zheng W, Du Y. Upregulation of zinc transporter 2 in the blood-CSF barrier following lead exposure. Exp Biol Med (Maywood). 2014;239(2):202-12.

84. Keep RF, Smith DE. Choroid plexus transport: gene deletion studies. Fluids Barriers CNS. 2011;8(1):26.

85. Nicolazzo JA, Katneni K. Drug transport across the blood-brain barrier and the impact of breast cancer resistance protein (ABCG2). Current topics in medicinal chemistry. 2009;9(2):13047.

86. Vogelgesang S, Cascorbi I, Schroeder E, Pahnke J, Kroemer HK, Siegmund W, et al. Deposition of Alzheimer's beta-amyloid is inversely correlated with P-glycoprotein expression in the brains of elderly non-demented humans. Pharmacogenetics. 2002;12(7):535-41.

87. Jablonski MR, Jacob DA, Campos C, Miller DS, Maragakis NJ, Pasinelli $\mathrm{P}$, et al. Selective increase of two $\mathrm{ABC}$ drug efflux transporters at the blood-spinal cord barrier suggests induced pharmacoresistance in ALS. Neurobiology of Disease. 2012;47(2):194-200.

88. Milane A, Vautier S, Chacun H, Meininger V, Bensimon G, Farinotti R, et al. Interactions between riluzole and ABCG2/BCRP transporter. Neuroscience letters. 2009;452(1):12-6.

89. Juliane Kläs, Hartwig Wolburg, Tetsuya Terasaki, Gert Fricker, Reichell V. Characterization of immortalized choroid plexus epithelial cell lines for studies of transport processes across the blood-cerebrospinal fluid barrier. Cerebrospinal Fluid Research. 2010;7(11):2-12.

90. Reichel V, Burghard S, John I, Huber O. Pglycoprotein and breast cancer resistance protein expression and function at the blood-brain barrier and blood-cerebrospinal fluid barrier (choroid plexus) in streptozotocin-induced diabetes in rats. Brain research. 2011;1370:23845.

91. Hosoya K, Hori S, Ohtsuki S, Terasaki T. A new in vitro model for blood-cerebrospinal fluid barrier transport studies: an immortalized choroid plexus epithelial cell line derived from the tsA58 SV40 large T-antigen gene transgenic 
rat. Advanced Drug Delivery Reviews. 2004;56(12):1875-85.

92. Watjen W, Weber N, Lou YJ, Wang ZQ, Chovolou Y, Kampkotter A, et al. Prenylation enhances cytotoxicity of apigenin and liquiritigenin in rat H4IIE hepatoma and C6 glioma cells. Food and chemical toxicology : an international journal published for the British Industrial Biological Research Association. 2007;45(1):119-24.

93. Sehdev V, Lai JCK, Bhushan A. Biochanin A Modulates Cell Viability, Invasion, and Growth Promoting Signaling Pathways in HER-2Positive Breast Cancer Cells. Journal of Oncology. 2009;2009:10.

94. Kole L, Giri B, Manna SK, Pal B, Ghosh S. Biochanin-A, an isoflavon, showed antiproliferative and anti-inflammatory activities through the inhibition of iNOS expression, p38MAPK and ATF-2 phosphorylation and blocking NFkappaB nuclear translocation. Eur J Pharmacol. 2011;653(1-3):8-15.

95. Wu MS, Lien GS, Shen SC, Yang LY, Chen YC. HSP90 Inhibitors, Geldanamycin and Radicicol, Enhance Fisetin-Induced Cytotoxicity via Induction of Apoptosis in Human Colonic Cancer Cells. Evidence-based complementary and alternative medicine : eCAM. 2013;2013:987612.

96. El-Readi MZ, Hamdan D, Farrag N, El-Shazly A, Wink M. Inhibition of P-glycoprotein activity by limonin and other secondary metabolites from Citrus species in human colon and leukaemia cell lines. Eur J Pharmacol. 2010;626(2-3):139-45.

97. Park H, Ra J, Hang M. Hesperidin induces apoptosis in SNU-668, human gastric cancer cells. Molecular Cell Toxicology. 2007(3):31-5.

98. Lee KA, Lee SH, Lee YJ, Baeg SM, Shim JH. Hesperidin Induces Apoptosis by Inhibiting Sp1 and Its Regulatory Protein in MSTO-211H Cells. Biomolecules \& therapeutics. 2012;20(3):273-9.

99. Cho YJ, Kim SJ. Effect of quercetin on the production of nitric oxide in murine macrophages stimulated with lipopolysaccharide from Prevotella intermedia. Journal of periodontal \& implant science. 2013;43(4):1917.

100. Cristina Marcarini J, Ferreira Tsuboy MS, Cabral Luiz R, Regina Ribeiro L, Beatriz Hoffmann-Campo C, Segio Mantovani M. Investigation of cytotoxic, apoptosis-inducing, genotoxic and protective effects of the flavonoid rutin in HTC hepatic cells. Experimental and toxicologic pathology : official journal of the Gesellschaft fur Toxikologische Pathologie. 2011;63(5):459-65.

101. Wu ML, Li H, Wu DC, Wang XW, Chen XY, Kong QY, et al. CYP1A1 and CYP1B1 expressions in medulloblastoma cells are AhRindependent and have no direct link with resveratrol-induced differentiation and apoptosis. Neuroscience letters. 2005;384(12):33-7.

102. Tsai TH. Determination of naringin in rat blood, brain, liver, and bile using microdialysis and its interaction with cyclosporin a, a p-glycoprotein modulator. Journal of agricultural and food chemistry. 2002;50(23):6669-74.

103. Tsai TH, Chen Y. Determination of Unbound Hesperetin in Rat Blood and Brain by Microdialysis Coupled to Microbore Liquid Chromatography. Journal of Food and Drug Analysis. 2000;8(4):331-6.

104. Schaffer S, Halliwell B. Do polyphenols enter the brain and does it matter? Some theoretical and practical considerations. Genes \& nutrition. 2012;7(2):99-109.

105. Mao Q, Unadkat JD. Role of the breast cancer resistance protein (ABCG2) in drug transport. The AAPS journal. 2005;7(1):E118-33.

106. Robey RW, To KK, Polgar O, Dohse M, Fetsch P, Dean M, et al. ABCG2: a perspective. Adv Drug Deliv Rev. 2009;61(1):3-13.

107. Sarkadi B, Homolya L, Szakacs G, Varadi A. Human multidrug resistance $\mathrm{ABCB}$ and $\mathrm{ABCG}$ transporters: participation in a chemoimmunity defense system. Physiological reviews. 2006;86(4):1179-236.

108. Kim M, Turnquist H, Jackson J, Sgagias M, Yan $\mathrm{Y}$, Gong $\mathrm{M}$, et al. The multidrug resistance transporter ABCG2 (breast cancer resistance protein 1) effluxes Hoechst 33342 and is overexpressed in hematopoietic stem cells. Clinical cancer research : an official journal of the American Association for Cancer Research. 2002;8(1):22-8.

109. Scharenberg CW, Harkey MA, Torok-Storb B. The ABCG2 transporter is an efficient Hoechst 33342 efflux pump and is preferentially expressed by immature human hematopoietic progenitors. Blood. 2002;99(2):507-12.

110. Seigel GM, Campbell LM. High-throughput microtiter assay for Hoechst 33342 dye uptake. Cytotechnology. 2004;45(3):155-60.

111. van Loevezijn A, Allen JD, Schinkel AH, Koomen GJ. Inhibition of BCRP-mediated drug efflux by fumitremorgin-type indolyl diketopiperazines. Bioorganic \& medicinal chemistry letters. 2001;11(1):29-32.

112. Imai Y, Ishikawa E, Asada S, Sugimoto Y. Estrogen-mediated post transcriptional downregulation of breast cancer resistance protein/ABCG2. Cancer research. 2005;65(2):596-604.

113. Tang F, Ouyang H, Yang JZ, Borchardt RT. Bidirectional transport of rhodamine 123 and Hoechst 33342, fluorescence probes of the binding sites on P-glycoprotein, across MDCKMDR1 cell monolayers. Journal of pharmaceutical sciences. 2004;93(5):1185-94.

114. van der Heijden J, de Jong MC, Dijkmans BA, Lems WF, Oerlemans R, Kathmann I, et al. 
Development of sulfasalazine resistance in human $\mathrm{T}$ cells induces expression of the multidrug resistance transporter ABCG2 (BCRP) and augmented production of TNFalpha. Annals of the rheumatic diseases. 2004;63(2):138-43.

115. Tomaru A, Morimoto N, Morishita M, Takayama K, Fujita T, Maeda K, et al. Studies on the intestinal absorption characteristics of sulfasalazine, a breast cancer resistance protein (BCRP) substrate. Drug metabolism and pharmacokinetics. 2013;28(1):71-4.

116. Donovan JL, Manach C, Faulks RM, Kroon PA. Absorption and metabolism of dietary secondary metabolites. In: Crozier A, Clifford $\mathrm{MN}$, Ashihara H, editors. Plant Secondary Metabolites Occurrence, Structure and Role in the Human Diet. Oxford, UK: Blackwell Publishing; 2006. p. 303-51.

117. Day AJ, Canada FJ, Diaz JC, Kroon PA, McLauchlan R, Faulds CB, et al. Dietary flavonoid and isoflavone glycosides are hydrolysed by the lactase site of lactase phlorizin hydrolase. FEBS letters. 2000;468(23):166-70.

118. Youdim KA, Dobbie MS, Kuhnle G, Proteggente AR, Abbott NJ, Rice-Evans C. Interaction between flavonoids and the bloodbrain barrier: in vitro studies. Journal of neurochemistry. 2003;85(1):180-92.

119. Youdim KA, Qaiser MZ, Begley DJ, RiceEvans CA, Abbott NJ. Flavonoid permeability across an in situ model of the blood-brain barrier. Free radical biology \& medicine. 2004;36(5):592-604.

120. Rangel-Ordonez L, Noldner M, SchubertZsilavecz M, Wurglics M. Plasma levels and distribution of flavonoids in rat brain after single and repeated doses of standardized Ginkgo biloba extract EGb 761(R). Planta medica. 2010;76(15):1683-90.

121. Peng HW, Cheng FC, Huang YT, Chen CF, Tsai TH. Determination of naringenin and its glucuronide conjugate in rat plasma and brain tissue by high-performance liquid chromatography. Journal of chromatography B, Biomedical sciences and applications. 1998;714(2):369-74.

122. Pool H, Quintanar D, Figueroa JdD, Marinho Mano C, Bechara JEH, God, et al. Antioxidant Effects of Quercetin and Catechin Encapsulated into PLGA Nanoparticles. Journal of Nanomaterials. 2012;2012:12.

123. Fatma S, Talegaonkar S, Iqbal Z, Panda AK, Negi LM, Goswami DG, et al. Novel flavonoidbased biodegradable nanoparticles for effective oral delivery of etoposide by P-glycoprotein modulation: an in vitro, ex vivo and in vivo investigations. Drug delivery. 2014:1-12.

124. Rahmanian N, Hamishehkar H, Dolatabadi JE, Arsalani N. Nano graphene oxide: A novel carrier for oral delivery of flavonoids. Colloids and surfaces B, Biointerfaces. 2014.

125. Liu M, Li H, Luo G, Liu Q, Wang Y. Pharmacokinetics and biodistribution of surface modification polymeric nanoparticles. Archives of pharmacal research. 2008;31(4):547-54.

126. Wang X, Chi N, Tang X. Preparation of estradiol chitosan nanoparticles for improving nasal absorption and brain targeting. European journal of pharmaceutics and biopharmaceutics : official journal of Arbeitsgemeinschaft fur Pharmazeutische Verfahrenstechnik eV. 2008;70(3):735-40.

127. Zensi A, Begley D, Pontikis C, Legros C, Mihoreanu L, Buchel C, et al. Human serum albumin nanoparticles modified with apolipoprotein A-I cross the blood-brain barrier and enter the rodent brain. Journal of drug targeting. 2010;18(10):842-8.

128. Tian XH, Wang ZG, Meng H, Wang YH, Feng $\mathrm{W}$, Wei F, et al. Tat peptide-decorated gelatinsiloxane nanoparticles for delivery of CGRP transgene in treatment of cerebral vasospasm. International journal of nanomedicine. 2013;8:865-76.

129. Tian XH, Wei F, Wang TX, Wang $\mathrm{P}$, Lin $\mathrm{XN}$, Wang $J$, et al. In vitro and in vivo studies on gelatin-siloxane nanoparticles conjugated with SynB peptide to increase drug delivery to the brain. International journal of nanomedicine. 2012;7:1031-41.

130. Rao KS, Reddy MK, Horning JL, Labhasetwar V. TAT-conjugated nanoparticles for the CNS delivery of anti-HIV drugs. Biomaterials. 2008;29(33):4429-38.

131. Mishra V, Mahor S, Rawat A, Gupta PN, Dubey $\mathrm{P}$, Khatri K, et al. Targeted brain delivery of AZT via transferrin anchored pegylated albumin nanoparticles. Journal of drug targeting. 2006;14(1):45-53.

132. Hoque MT, Robillard KR, Bendayan R. Regulation of breast cancer resistant protein by peroxisome proliferator-activated receptor alpha in human brain microvessel endothelial cells. Mol Pharmacol. 2012;81(4):598-609.

133. Huang W, Rha GB, Han MJ, Eum SY, Andras IE, Zhong Y, et al. PPARalpha and PPARgamma effectively protect against HIVinduced inflammatory responses in brain endothelial cells. Journal of neurochemistry. 2008;107(2):497-509.

134. von Wedel-Parlow M, Wolte P, Galla HJ. Regulation of major efflux transporters under inflammatory conditions at the blood-brain barrier in vitro. Journal of neurochemistry. 2009;111(1):111-8.

135. Poller B, Drewe J, Krahenbuhl S, Huwyler J, Gutmann H. Regulation of BCRP (ABCG2) and P-glycoprotein (ABCB1) by cytokines in a model of the human blood-brain barrier. Cellular and molecular neurobiology. 2010;30(1):63-70. 
136. Bauer B, Yang X, Hartz AM, Olson ER, Zhao $\mathrm{R}$, Kalvass JC, et al. In vivo activation of human pregnane $\mathrm{X}$ receptor tightens the blood-brain barrier to methadone through P-glycoprotein upregulation. Mol Pharmacol. 2006;70(4):1212-9.

137. Wang X, Sykes DB, Miller DS. Constitutive androstane receptor-mediated up-regulation of ATP-driven xenobiotic efflux transporters at the blood-brain barrier. Mol Pharmacol. 2010;78(3):376-83.

138. Mahringer A, Fricker G. BCRP at the bloodbrain barrier: Genomic regulation by $17 \beta-$ estradiol. Molecular Pharmaceutics. 2010;7(5):1835-47.

139. Tan KP, Wang B, Yang M, Boutros PC, Macaulay J, Xu H, et al. Aryl hydrocarbon receptor is a transcriptional activator of the human breast cancer resistance protein (BCRP/ABCG2). Mol Pharmacol. 2010;78(2):175-85.

140. Wu XG, Peng SB, Huang Q. [Transcriptional regulation of breast cancer resistance protein]. Yi chuan $=$ Hereditas $/$ Zhongguo yi chuan xue hui bian ji. 2012;34(12):1529-36.

141. Ebert B, Seidel A, Lampen A. Identification of $\mathrm{BCRP}$ as transporter of benzo[a]pyrene conjugates metabolically formed in Caco-2 cells and its induction by Ah-receptor agonists. Carcinogenesis. 2005;26(10):1754-63.

142. Tompkins LM, Li H, Li L, Lynch C, Xie Y, Nakanishi $T$, et al. A novel xenobiotic responsive element regulated by aryl hydrocarbon receptor is involved in the induction of $\mathrm{BCRP} / \mathrm{ABCG} 2$ in LS174T cells. Biochemical pharmacology. 2010;80(11):175461.

143. Faria A, Meireles M, Fernandes I, SantosBuelga C, Gonzalez-Manzano S, Duenas M, et al. Flavonoid metabolites transport across a human BBB model. Food chemistry. 2014;149:190-6.

144. Faria A, Pestana D, Teixeira D, Couraud PO, Romero I, Weksler B, et al. Insights into the putative catechin and epicatechin transport across blood-brain barrier. Food \& function. 2011;2(1):39-44.

145. Hartz AM, Miller DS, Bauer B. Restoring blood-brain barrier P-glycoprotein reduces brain amyloid-beta in a mouse model of Alzheimer's disease. Mol Pharmacol. 2010;77(5):715-23. 